\title{
Mitigating Effects of Beta-Carotene on Hydroponic Growth and Productivity of Amaranthus Hybridus L. under Aluminium Toxicity Induced Stress
}

Uchenna Oliver Egedigwe ( $\nabla$ uchenna.egedigwe@unn.edu.ng )

University of Nigeria https://orcid.org/0000-0002-4808-5336

Obi Sergius Udengwu

University of Nigeria

\section{Research Article}

Keywords: Aluminium toxicity, Amaranthus hybridus, $\beta$-Carotene, Growth and productivity, Hydroponics, Stress amelioration.

Posted Date: July 19th, 2021

DOl: https://doi.org/10.21203/rs.3.rs-645347/v1

License: (c) (i) This work is licensed under a Creative Commons Attribution 4.0 International License.

Read Full License 


\section{Abstract}

Aluminium (Al) toxicity is one of the major sources of environmental stress that limit plant growth and productivity in many acidic soils, especially in the tropics and sub-tropics. Al toxicity subsequently leads to food insecurity in developing countries, especially in sub-Saharan Africa. Though plants can synthesize their antioxidants; the need exists to investigate whether under Al toxicity-induced stress; betacarotene ( $\beta$-Carotene) supplementation could ameliorate the stress situation and enhance growth and productivity. $\mathrm{A} 3 \times 10^{-2} \mathrm{mM}$ aluminium chloride $\left(\mathrm{AlCl}_{3}\right)$ at $\mathrm{pH} 4.6$ was used to stress plants. $\beta$-Carotene was extracted from carrots and high-performance liquid chromatography (HPLC) was used to determine its peak absorbance at $295 \mathrm{~nm}$. $\beta$-Carotene's activity was determined using the thiobarbituric acid method. The effects of 50 and $200 \mu \mathrm{M}$ concentrations of $\beta$-Carotene on the hydroponic growth of Amaranthus hybridus, subjected to Al stress, were evaluated in this study. Pre- and post- $\beta$-Carotene treatments were applied to $A$. hybridus seedlings before and after Al treatment for $72 \mathrm{~h}$. Results showed that post- $\beta$-Carotene treatments significantly ameliorated plants from Al stress when compared to pre- $\beta$ Carotene treatments. Higher doses of $\beta$-Carotene significantly increased leaf number, plant height, length and number of inflorescence, fresh and dry weights of shoot, root and inflorescence but significantly decreased root length. The present study suggests that plants of $A$. hybridus were susceptible to Al toxicity-induced stress and post- $\beta$-Carotene supplementation could significantly ameliorate the stress situation and enhance growth and productivity. However, intrinsic antioxidants could be adequate for plants not subjected to stress.

\section{Introduction}

Aluminium (Al) toxicity is an important growth-limiting factor for plants in acid soils below pH 5.0 and is responsible for shortages in food production (Blue and Dantzman, 1977; Alak and Adams 1979; De Carvalho et al. 1980; Foy et al. 1992; Seguel et al. 2013; Nunes-Nesi et al. 2014; Soto-Cerda et al. 2015; Rahman and Upadhyaya 2021) and major stress agents that reduce crop productivity and increase food insecurity in the tropics and Sub-Saharan Africa (Kochian 1995; Hede et al. 2001; Rengel et al. 2015). Al is the third most abundant element making up over $8 \%$ of the earth's crust (Inostroza-Blancheteau et al. 2012; Bhalerao and Prabhu 2013; Rengel et al. 2015; Schmitt et al. 2016; Jaskowiak et al. 2019).

The general population is exposed to Al from its widespread use in water treatment, food additive, various Al-based pharmaceuticals, toothpaste, antiperspirants, pollutants from electrical power stations, industrial activities and automobile exhaust as well as from Al containers/packaging materials and cooking utensils (Harris et al. 1996; Ma et al. 2001; Pournourmohammadi et al. 2008). Al is solubilized into toxic forms such as hexaaquaaluminium $\left([\mathrm{Al}(\mathrm{H} 2 \mathrm{O}) 6]^{3+}\right)$; mononuclear species $\left[\mathrm{Al}(\mathrm{OH})^{2+}\right]$ or $\left[\mathrm{Al}(\mathrm{OH})^{2+}\right.$; gibbsite $\left[\mathrm{Al}(\mathrm{OH})_{3}\right]$; aluminate $\left[\mathrm{Al}(\mathrm{OH})^{4-}\right] ; \mathrm{AlCl}_{3}$ and are generally referred to as $\mathrm{Al}^{3+}$ (Kinraide 1990; Abreu et al. 2003; Silva 2012; Schmitt et al. 2016). Soil pH, chemical structure and composition of soluble Al compounds in soil solution as well as the solution's ionic strength have played key roles in Al toxicity (Siecinska and Nosalewicz 2017). Al toxicity affects plants directly and is transferred to humans 
and animals that consume these plants via the food chain (Fatur et al. 2002; Savvas et al. 2010; Rahman and Upadhyaya 2021).

Some of the most noticeable phytotoxic symptoms of Al toxicity include inhibition of root growth (Silva 2012; Kopittke et al. 2015; Rosmaninho et al. 2019), leaf-chlorosis, and stunted plant growth (Gupta et al. 2013; Vasconcelos et al. 2020). The roots exhibit greater signs of cellular damage than the other parts of the plant (Wagatsuma et al. 1987; Rincón and Gonzales 1992; Udengwu and Egedigwe 2014; Kochian et al. 2015). Under Al stress in a nutrient solution, Al-sensitive genotypes were characterized by chlorosis (Udengwu and Egedigwe 2014), decreased Fe concentration in tops, decreased/inhibited Ca and $\mathrm{Mg}$ uptake in both shoots and roots (Horst et al. 2010; Bose et al. 2011), a tendency towards the accumulation of P, Al, and Fe in roots and reduced $\mathrm{Mn}$ in tops (Foy and Fleming 1982; Gupta et al. 2013). Studies have shown that Al adversely affected several physiological activities, producing severe physiological stress which increased peroxidase activity (Peters et al. 1989; Kochian et al. 2015; Rengel et al. 2015; Rouphael et al. 2016). Al toxicity induces oxidative stress that elicits the production of reactive oxygen species (ROS) (Darkó et al. 2004; Jones et al. 2006; He et al. 2014; Singh et al. 2017) that may damage cellular components if surrounding antioxidant enzymes are suppressed (Darkó et al. 2004; Sharma and Dubey 2007; Bera et al. 2019; Shahnawaz and Sanadhya 2019; Devi et al. 2020). Cytological studies show that Al toxicity results in cell cycle disturbances and a decrease in Mitotic Index (MI) value (Wierzbicka 1988, 1989; Samardakiewicz and Woźny 2005; Nezames et al. 2012) as well as induces Cmitosis, micronuclei, chromosome stickiness, budding nuclei, laggards and chromosome bridges (Aslanturk and Celik, 2005; Zhang et al. 2014). Given the menace of Al toxicity, especially in the subSaharan region, current research is now geared towards proffering long-term solutions to mitigate the devastating effects of Al toxicity on crop yield and productivity.

It is pertinent to point out that studies have attributed low pH to be the major cause of stress and the ignition to the production of ROS (Samac and Tesfaye 2003; Inostroza-Blancheteau et al. 2012; Udengwu and Egedigwe 2014; Yang et al. 2015; Rahman and Upadhyaya 2021). Previous studies concerning Al toxicity have focused only on Al being the major cause of stress limiting crop productivity but in reality, low pH sets the stage for Al to become toxic. Al toxicity not only depends on its total concentration but also its chemical forms that wholly depend on low pH (Kochian 1995). Hence, there is a significant correlation between high concentrations of Al3 + in the soil and low pH (Rout et al. 2001; BojórquezQuintal et al. 2017; Palani et al. 2018).

There is growing evidence from in vitro and in vivo laboratory animal studies that $\beta$-Carotene can protect phagocytic cells from auto-oxidative damage, enhance $T$ and $B$ lymphocyte proliferating responses, stimulate effector T-cell functions, and enhance macrophage, cytotoxic T- cell and natural killer cell tumoricidal capacities, as well as increase the production of certain interleukins (Bendich 1989; Mueller and Boehm 2011; Esrefoglu et al. 2016). Many of these effects have also been seen with carotenoids lacking provitamin A activity but having the antioxidant and singlet oxygen quenching capacities of $\beta$ Carotene, however, reports have it that $\beta$-Carotene could be converted into vitamin $A$, which is essential for normal growth and development (Lemmens et al. 2010; Giuliano et al. 2017)). Since vitamin A is a 
relatively poor antioxidant and cannot quench singlet oxygen, $\beta$-Carotene may have more importance as a nutrient than simply serving as a precursor of vitamin A (Bendich 1989). Carotenoids, including $\beta$ Carotene, are very efficient at quenching singlet oxygen (Di Mascio et al. 1989; Baltschun et al. 1997).

Stahl and Sies (2003) have shown that $\beta$-Carotene undergo different configurations (either cis or trans isomers) because of their double bonds. Growing observations have also showed that most carotenoids isomerize to their cis-configuration during thermal procession and extraction (Lemmens et al. 2010), storage conditions due to light acids and oxygen (Rao and Rao 2007), thus leading to loss of colour and reduction in biological activities. However, the all-trans isomer may exist predominantly in nature.

Though evidence for carotenoids roles' in animals and humans are ubiquitous, studies about the supplementation of plants with $\beta$-Carotene are scarce. However, lycopene had ameliorating effects on chromosome aberrations in Allium cepa (Aslanturk and Celik 2005); while a higher concentration of lycopene alleviated and bolstered plants of $A$. hybridus from the devastating effects of Al-induced stress (Udengwu and Egedigwe 2014). It is well known that animals cannot synthesize carotenoids because they lack chromoplasts and thus depend on plants for the nutritious and protective values of carotenoids. However, Moran and Jarvik (2010) showed that some aphids manufacture toluene de novo.

A. hybridus, being a staple vegetable eaten in the tropics, is sensitive to low concentrations of Al and such low concentrations subjected the same plant to stress and reduced growth and productivity (Udengwu and Egedigwe 2014). In another study, Osaki et al. (1997) classified A. hybridus and some other tropical plants under the Al-sensitive group. Despite the intrinsic antioxidants inherent in plants, some plants, including staple crops, may not be capable of synthesizing high levels of antioxidants during stress situations and thus cause devastating damages to plant growth and yield. Excessive reduction in crop yield and productivity have consequently led to food insecurity in sub-Saharan regions. The current study, therefore, explores the role of supplementary $\beta$-Carotene in mitigating plants of $A$. hybridus exposed to $\mathrm{Al}$ toxicity via pre- and post- $\beta$-Carotene applications.

\section{Materials And Methods}

\section{Soil Analysis}

Topsoil for raising nursery plants was collected from the Botanic Garden, University of Nigeria Nsukka. The soil sample was air-dried and analysed in the Soil Science Analytical Laboratory in the Department of Soil Science, University of Nigeria Nsukka. The soil was analysed using the standard method of the Association of Official Analytical Chemists (2005).

\section{$\beta$-Carotene extraction and purification}

Extraction and purification of $\beta$-Carotene were carried out following the methods of Udengwu and Egedigwe (2014). Fresh and matured carrots weighing $15 \mathrm{~kg}$ were purchased from Nsukka local market. $\beta$ - 
Carotene crystals were got following the methods of Yaping et al. (2002). Extracted $\beta$-Carotene was protected from light and stored at $2^{\circ} \mathrm{C}$ to avoid transformation to inactive isomers.

\section{Determination of antioxidant activity}

Adapting the methods of Udengwu and Egedigwe (2014), thiobarbituric acid (TBA) value was used to determine the antioxidant activity of $\beta$-Carotene. All readings were taken thrice and antioxidant activities were calculated as follows using the method of Hanachi and Sh (2009).

$\%$ Antioxidant Activity $=\frac{A B \text { control }- \text { ABsample }}{A B \text { control }} \times 100$

Where $A B_{\text {sample }}=A b$ sorbance of sample and $A B_{\text {control }}=$ Absorbance of control

\section{High-performance liquid chromatography analysis (HPLC)}

The percentage (\%) purity of the extracted $\beta$-Carotene was determined using the methods of Udengwu and Egedigwe (2014). HPLC was done in the Department of Pure and Industrial Chemistry, University of Nigeria Nsukka, while UV spectrometry was determined using a UV-visible spectrophotometer. Readings of $\beta$-Carotene standard in ethanol were taken to confirm the peak absorbance of extracted $\beta$-Carotene.

\section{Stock preparations}

Fresh $1 \mathrm{M}$ stock solutions of $\beta$-Carotene, $\mathrm{AlCl}_{3}$, and full Hoagland's nutrient were prepared daily using the methods of Udengwu and Egedigwe (2014). They were stored at $4^{\circ} \mathrm{C}$ in the refrigerator before use.

$\beta$-Carotene stock solution: One gram of $\beta$-Carotene was mixed in $10 \mathrm{~mL}$ of ethanol before the addition of $990 \mathrm{~mL}$ of distilled water. A $1 \%$ alcohol dilution of $\beta$-Carotene was used in this study following the protocol of Fiskesjo (1981); who showed that $1 \%$ of alcohol dilutions of lipophilic solutes were not toxic to Allium roots.

\section{$\mathrm{AlCl}_{3}$ stock solution (1 Molar)}

This was prepared by dissolving $133.5 \mathrm{~g}$ of $\mathrm{AlCl}_{3}$ in little distilled water and the final volume made up to $1000 \mathrm{~mL}$. The $\mathrm{pH}$ of the solution was buffered to 4.6 .

\section{Al treatment concentration}

Al treatment concentration of $3 \times 10^{-2} \mathrm{mM}$ was achieved through serial dilution and $\mathrm{pH} 4.6$ was through adjustments with $\mathrm{H}_{2} \mathrm{SO}_{4}$.

\section{Hoagland's nutrient solution}

This was prepared using the formulation of Hoagland and Arnon (1950 revised).

\section{Determination of actual Al concentration in solution}


Actual Al in solution was determined using Shull (1960) modified Aluminon method for aluminium determination.

\section{Growing Amaranthus hybridus}

Viable Amaranthus seeds were obtained from the Amaranthus germplasm maintained in the Botanic Garden, University of Nigeria, Nsukka. Seeds maintained in the germplasm were acquired from National Horticultural Research Institute (NIHORT), Ibadan Nigeria. The exact methods of Udengwu and Egedigwe (2014) were used to grow Amaranthus plants. Plants were arranged using a randomized complete block design (RCBD) in the screen house of the Botanic garden. Five plants per treatment, replicated three times, were used to monitor the growth of plants. Plants were allowed to stabilize in full strength Hogland's nutrient solution for $10 \mathrm{~d}$ before the 8 treatments were applied (Table 1). All plants received treatments for 21 days. Using a non-continuous flow system, all treatments were renewed daily to ensure adequate nutrient supply and uniformity of treatment. When treatment application elapsed, the experiment was terminated. Fresh and dry weights of shoots, roots and inflorescences, as well as other growth parameters such as the numbers of leaves and inflorescences, plant height, root length, length of inflorescence, were evaluated and recorded. 
Table 1

Details of the 8 Treatments given to experimental plants

\begin{tabular}{|c|c|c|c|c|}
\hline $\mathrm{S} / \mathrm{N}$ & $\begin{array}{l}\text { Type of } \\
\text { Treatment }\end{array}$ & Abbreviation & Symbol & Details \\
\hline 1. & $\begin{array}{l}\beta \text {-carotene } \\
(50 \mu \mathrm{M})\end{array}$ & $\mathrm{bc}_{1}$ & T1 & $\begin{array}{l}\text { Amaranthus plants (AP) were grown in } \\
\text { Hoagland's nutrient solution (HNS) and } 50 \mu \mathrm{M} \\
\text { bc }_{1} \text { for } 21 \mathrm{~d}\end{array}$ \\
\hline 2. & $\begin{array}{l}\text { B-carotene } \\
(200 \mu \mathrm{M})\end{array}$ & $\mathrm{bc}_{2}$ & T2 & 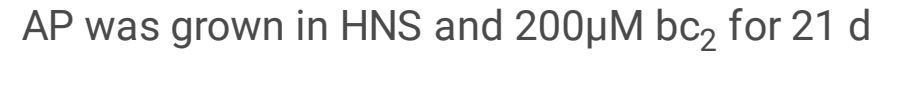 \\
\hline 3. & $\begin{array}{l}\text { Pre- } \beta \text {-carotene } \\
(50 \mu \mathrm{M})\end{array}$ & $\left(\mathrm{bc}_{1}-\mathrm{Al}\right)$ & T3 & $\begin{array}{l}\text { AP was grown in HNS and } 50 \mu \mathrm{M} \mathrm{bc}_{1} \text { for } 72 \mathrm{~h} \\
\text { before transfer into HNS and } 3 \times 10^{-2} \mathrm{mM} \text { Al for } \\
18 \mathrm{~d} \text {. }\end{array}$ \\
\hline 4. & $\begin{array}{l}\text { Pre- } \beta \text {-carotene } \\
(200 \mu \mathrm{M})\end{array}$ & $\left(\mathrm{bc}_{2}-\mathrm{Al}\right)$ & T4 & $\begin{array}{l}\text { AP was grown in HNS and } 200 \mu \mathrm{M} \mathrm{bc}_{2} \text { for } 72 \mathrm{~h} \\
\text { before transfer into HNS and } 3 \times 10^{-2} \mathrm{mM} \text { Al for } \\
18 \mathrm{~d} \text {. }\end{array}$ \\
\hline 5. & $\begin{array}{l}\text { Post- } \beta- \\
\text { carotene } \\
(50 \mu \mathrm{M})\end{array}$ & $\left(\mathrm{Al}-\mathrm{bc}_{1}\right)$ & T5 & 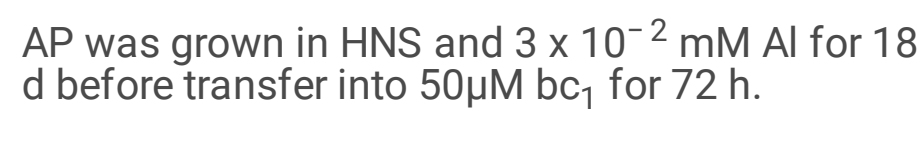 \\
\hline 6. & $\begin{array}{l}\text { Post- } \beta- \\
\text { carotene } \\
(200 \mu \mathrm{M})\end{array}$ & $\left(\mathrm{Al}-\mathrm{bc}_{2}\right)$ & T6 & $\begin{array}{l}\text { AP was grown in HNS and } 3 \times 10^{-2} \mathrm{mM} \text { Al for } 18 \\
\mathrm{~d} \text { before transfer into } 200 \mu \mathrm{M} \mathrm{bc}_{2} \text { for } 72 \mathrm{~h} \text {. }\end{array}$ \\
\hline 7. & $\begin{array}{l}\text { Aluminium (3 } \\
\left.\times 10^{-2} \mathrm{mM}\right)\end{array}$ & $\mathrm{Al}$ & T7 & AP grown into HNS and $3 \times 10^{-2} \mathrm{mM}$ for $21 \mathrm{~d}$ \\
\hline 8. & Control & Ctrl & C & AP grown into HNS for $21 \mathrm{~d}$ \\
\hline
\end{tabular}

\section{Statistical analysis}

Data collected from growth studies were analysed with one-way analysis of variance (ANOVA). The Least Significant Difference (LSD) was used to separate means at $P \leq 0.05$ level of significance. SPSS v23, Microsoft Excel 2016 and Gen-Stat packages were used for computation, data analysis and graphics.

\section{Results}

\section{Soil analysis}

The result of soil analysis was the same as the results of Udengwu and Egedigwe (2014). Results showed no presence of Al (Table 2). 
Table 2

Physical and chemical composition of the topsoil in the Botanic Garden, University of

Nigeria, Nsukka, used for seed germination and seedling production (Udengwu and Egedigwe 2014)

\begin{tabular}{|ll|}
\hline Parameters & Values \\
\hline $\mathrm{pH}\left(\mathrm{H}_{2} \mathrm{O}\right)$ & 6.200 \\
$\mathrm{pH}(\mathrm{KCl})$ & 5.200 \\
Fine soil (\%) & 29.000 \\
Silt (\%) & 5.000 \\
Clay (\%) & 27.000 \\
Coarse soil (\%) & 39.000 \\
Organic matter (\%) & 5.779 \\
Organic Carbon (\%) & 3.352 \\
Total Nitrogen (\%) & 0.168 \\
Available P (ppm) & 37.370 \\
Exchangeable cations (mg/100g) & 31.200 \\
Calcium (mg/100g) & 8.800 \\
Magnesium (mg/100g) & 15.200 \\
Sodium (mg/100g) & 0.501 \\
Potassium (mg/100g) & 0.131 \\
Hydrogen ion (mg/100g) & 3.400 \\
\hline
\end{tabular}

\section{Antioxidant activity}

The antioxidant activity of $\beta$-Carotene, $72 \%$, differed significantly from ethanol blank, which exhibited a lower percentage activity. Rhee (1978) explained that the TBA test was a colorimetric technique used in measuring the absorbance of a red chromogen formed between TBA and malondialdehyde (MDA). Peak absorbance of extracted $\beta$-Carotene at $295 \mathrm{~nm}$ was 0.181 .

\section{Hydrogen ion concentration}

Using the formula of Stephenson (2010), the $\mathrm{H}^{+}$concentration of extracted $\beta$-Carotene at $\mathrm{pH} 5.8$ was determined by taking 10 to the power of the negative $\mathrm{pH}$ i.e., $10^{-5.8}$ which is equivalent to $1.5 \times 10^{-6} \mathrm{~mol}$ $\mathrm{L}^{-1}$ while the $\mathrm{H}^{+}$concentration of $3 \times 10^{-2} \mathrm{mM}$ of Al at pH 4.6 was calculated to be $2.5 \times 10^{-5} \mathrm{~mol} \mathrm{~L}^{-1}$. 
Following the Aluminon protocol, the actual Al concentration in solution used for the study was 1.85 $\mathrm{mg} / \mathrm{L}$.

\section{Vegetative and reproductive data.}

Before treatment applications, Amaranthus plants stabilized and were acclimatized in full strength Hoagland's nutrient solution (Fig. 1). The first noticeable symptoms observed three days after Al treatment applications, which was the same as the results of Udengwu and Egedigwe (2014), were prominent inhibition of root growth (Fig. 2), yellowing and wilting of leaves and overall stunting plant growth (Fig. 3).

Number of leaves (NOL) At the end of 21 days, Al-bc 2 (T6) significantly yielded a higher number of leaves in comparison with other treatments except control (Ctrl). Only T6, a post- $\beta$-Carotene treatment, significantly yielded more leaves than that observed in pre- $\beta$-Carotene treatments, $\mathrm{bc}_{1}-\mathrm{Al}$ (T3) and bc $\mathrm{b}_{2}-\mathrm{Al}$ (T4). Al treatment (Al) (T7) significantly reduced the number of leaves by $44.1 \%$ in comparison with the control (Fig. 4).

Plant height (PLH) Increasing concentrations of post $\beta$-Carotene treatments, Al-bc ${ }_{1}$ (T5) and T6, significantly increased plant height compared to increasing concentrations of pre- $\beta$-Carotene treatments (T3 and T4). Figure 5 shows that in T7, there was a significant reduction (36.5\%) in PLH when compared with control plants (Fig. 6).

Length of inflorescence (LOI) Fig. 7 shows that the least LOI was recorded with T3. Lengths of inflorescences from all treatments differed significantly from $\mathrm{T} 6$. Al (T7) significantly reduced the length of inflorescence by $37 \%$.

Number of inflorescences (NOI) As shown in Fig. 8, T6 yielded the highest number of inflorescence and differed significantly from other treatments. T7 significantly reduced the number of inflorescences. Treatments, $\mathrm{bc}_{2}$ (T2) and T3 significantly reduced the number of inflorescences by $88.6 \%$ and $95.2 \%$ respectively. Post- $\beta$-Carotene treatments ( $T 5$ and T6) yielded a higher number of inflorescences when compared to pre- $\beta$-Carotene treatments (T3 and T4).

Fresh weight of inflorescence (FWI) Responses of plants to all treatments in Fig. 9 significantly reduced FWI in comparison with control. There were no significant differences in FWI between pre- $\beta$-Carotene and post- $\beta$-Carotene treatments, except T6. Having a similar trend with the results got in LOI and NOI, T2 and T3 significantly reduced FWI by $86.5 \%$ and $97 \%$ respectively.

Dry weight of inflorescence (DWI) Responses of plants to treatments in Fig. 10 followed the exact trend with plants responses to treatments in FWI. The reduction in DWI was not significant in comparison with that of control plants. Responses of plants to T6 and T7 did not differ significantly from each other but differed significantly from other treatments, including control. 
Fresh weight of shoot (FWS) Decreasing pre- $\beta$-Carotene concentrations increased FWS, however, increasing post $\beta$-Carotene concentrations were directly proportional to a significant gain in FWS. All treatments significantly reduced FWS except T6. Responses of plants to T6 significantly differed from that of T1, T2, T3, T4, T5 and T7 (Fig. 11).

Dry weight of shoot (DWS) Fig. 12 shows that decreasing pre- $\beta$-Carotene concentrations increased DWS while increasing post- $\beta$-Carotene concentrations significantly increased DWS. Only T6 differed significantly from other treatments except for the control. Though not significant, responses of plants to T1 and T2 yielded higher DWS compared to T3, T4, T5 and T7. The least DWS was produced with T4.

Root length (ROL) Root length of control plants differed significantly from the rest of the treatments. The response of plants to $\mathrm{bc}_{1}(\mathrm{~T} 1)$ significantly reduced $\mathrm{ROL}$ and differs significantly from plants responses to T2, T4, T5 T6, T7 (Fig. 13) and control (Fig. 14). The least ROL was recorded with T6. Decreasing $\beta$ Carotene concentrations across treatments were directly proportional to longer ROL. Though there were no significant differences, pre- $\beta$-Carotene treatments prolonged root lengths more than post- $\beta$-Carotene treatments.

Fresh weight of root (FWR) Increasing concentrations of pre- $\beta$-Carotene treatments did not significantly increase FWR except in post- $\beta$-Carotene gain in concentration (Fig. 15). There was no significant reduction by T7 in comparison with control. Responses of plants to T1 and T6 increased FWR by $20 \%$ and $68.2 \%$ respectively.

Dry weight of root (DWR) The responses of plants to T3 and T5 recorded the highest and least DWR respectively compared to Control (Fig. 16). T7, T6, T1 and T3 treatments increased DWR by $13.5 \%, 18.9 \%$, $41.8 \%$ and $131.3 \%$ respectively. Increasing $\beta$-Carotene concentrations increased DWR except in post- $\beta$ Carotene increment.

\section{Discussion}

The results of soil analysis used in this study are the same as the results of Udengwu and Egedigwe (2014). It follows that $\mathrm{Al}$ was completely absent in the soil used and that aluminium chloride $\left(\mathrm{AlCl}_{3}\right)$ is the only source of Al used in this study. In comparison with the study of Udengwu and Egedigwe (2014), the findings of this study still showed that Al, at a low concentration of $3 \times 10^{-2} \mathrm{mM}$ and low pH of 4.6, significantly reduced both vegetative and reproductive growths of A. hybridus (Inine oma) except in FWR, DWR and DWI. This conforms to the findings of other studies that Al toxicity may not affect plants except under low pH conditions (Moore 1974; Dickson 1978). In essence, Udengwu and Egedigwe (2014) grouped A. hybridus as an Al-sensitive plant in the tropics. Tamás et al. (2006) reported that Hordeum vulgare (barley) roots represented only $20 \%$ of the control when plants were subjected to $10 \mathrm{mM}$ Al for 12 h. Plants were grown in Hoagland's nutrient solution to eliminate uncertainties of roots absorbing unknown amounts of different nutrient elements and other toxic metals if grown in soil. There is also an added advantage of the ease in controlling the $\mathrm{pH}$. Using transparent bottles allowed for full monitoring 
of roots during growth and unwanted cutting of root tips if grown in soil. Despite these advantages, it is important to mention that the growth of Amaranthus plants in nutrient solution will not be as robust as when grown in soil because $A$. hybridus is not an aquatic plant. It is quite interesting to point out the similar trend plants responded to the respective treatments via the growth parameters except for the situations in ROL and DWR. This shows that responses of experimental plants to independent $\beta$-Carotene treatments (T1 and T2) and pre- $\beta$-Carotene treatments (T3 and T4) were, perhaps, redundant until $\mathrm{Al}$ (T7) was applied (T6). The response of T7 in comparison with T6 significantly reduced growth for NOL, PLH, LOI, NOI, FWS, FWR, and DWS but was non-significant for DWR and DWI. Udengwu and Egedigwe (2014) attributed the decrease in growth to prior treatment of $A$. hybridus plants to Al for $21 \mathrm{~d}$ at $4.6 \mathrm{pH}$ and higher $\mathrm{H}^{+}$concentration of $2.5 \times 10^{-5} \mathrm{~mol} \mathrm{~L}^{-1}$ before transfer to lycopene solutions for only $72 \mathrm{~h}$, at a pH of 5.8 and lower $\mathrm{H}^{+}$concentration of $1.5 \times 10^{-6} \mathrm{~mol} \mathrm{~L}^{-1}$. Interestingly, Al-stressed plants grown in $\mathrm{T} 5$ and T6 recovered significantly for NOL, PLH, LOI, NOI, FWS, FWR and DWS, but non-significantly for FWI, DWR and DWI. From the findings of Udengwu and Egedigwe (2014), lycopene did not ideally recover plants from Al stress as much as $\beta$-Carotene ameliorated Al-stressed plants in this study. It could then be deduced that $\beta$-Carotene possesses a higher antioxidant power in combating Al-related stress, though both lycopene and $\beta$-Carotene contain the same number of conjugated double bonds, as well as $\beta$ Carotene, being a derivative of lycopene. Several studies have attributed $\beta$-Carotene's anti-oxidative activity to its high number of conjugated double bonds (Woodall et al. 1997; Muller and Boehm, 2011). Miller et al. (1996) reported that the properties underlying the activities of carotenoids towards free radicals and their scavenging effects related particularly to their abilities to donate electrons or hydrogen atoms and their relative propensities to undergo oxidation. Further studies are needed to explore whether the functional groups on the $\beta$-ionone ring of $\beta$-Carotene are responsible for the extra antioxidant activity of the carotenoid compared to lycopene.

Increased concentration of independent $\beta$-Carotene treatments ( $\mathrm{T} 1$ and $\mathrm{T} 2$ ), though not significant, reduced growth for all growth parameters except for $\mathrm{ROL}$, where a significant reduction in growth was recorded with increased $\beta$-Carotene dosage. On the other hand, with the introduction of Al stress (T3 to T6), $\beta$-Carotene's ameliorative effect was non-significant in plant growth (for all parameters except ROL and DWR) when concentrations were increased. It could be possible that the activity of $\beta$-Carotene becomes functional upon inducement of $\mathrm{Al}$ stress and that the Al-stressed plants absorbed the supplemented $\beta$-Carotene because intrinsic and stress-induced antioxidant enzymes were not enough for the stressed plants to recover from the stress condition caused by Al toxicity (Udengwu and Egedigwe 2014). Thus, the generation of antioxidant enzymes and antioxidant response elements (ARE) has been strongly linked to stressed environments (Boscolo et al. 2003; Siminovicova, 2004; Sharma and Dubey 2007; Aftab et al. 2010). The significant increase in plant growth of post- $\beta$-Carotene treatments (T5 and T6), (in almost all parameters except ROL and DWR), was more than that observed in pre- $\beta$-Carotene treatments (T3 and T4). The major reason for this has been attributed to stressed plants not needing $\beta$ Carotene supplementation when not stressed (T1 and T2) until the introduction of Al stress (T3 and T4) (Udengwu and Egedigwe 2014). They explained that $A$. hybridus that are not under stress may not need supplemented antioxidants because they are adequately protected by their intrinsic antioxidants and that 
these antioxidants mitigate stress conditions and not serving as growth stimulants. From the results obtained, it is suggestive that an increased dose of $\beta$-Carotene concentration (T2) given to plants for $72 \mathrm{~h}$ after Al stress yielded a significant ameliorative effect for all cases except ROL and DWR. This suggests that $A$. hybridus plants significantly absorbed $\beta$-Carotene when under Al stress and not before Al stress. Perhaps, $\beta$-Carotene may have yielded a better ameliorative effect when the dose was further increased (Udengwu and Egedigwe 2014). The difference in plant growth of T1 in comparison with T2 was significantly higher for only ROL, but was insignificant for other growth parameters. Having in mind that $\mathrm{T} 1$ and $\mathrm{T} 2$ each had a $\mathrm{pH}$ of 5.8 and $\mathrm{H}^{+}$concentration of $1.5 \times 10^{-6} \mathrm{~mol} \mathrm{~L}^{-1}$, the reason for the lower insignificant growth decrease of T2 over T1 could be that T1 was optimum in ameliorating stress (caused by $\mathrm{H}^{+}$) better than $\mathrm{T} 2$ where $\beta$-Carotene activity could have been redundant. This could buttress the assumption that plants need not be supplemented with $\beta$-Carotene except under stress conditions. The effect of Al in plants receiving T3 and T4 showed there was a significant growth decrease in the scenarios for $\mathrm{PLH}, \mathrm{LOI}, \mathrm{NOI}, \mathrm{FWI}$ and $\mathrm{DWI}$, however, $\beta$-Carotene significantly improved Al stress in the case of DWR. The possible reason for this is that transferring plants to Al (T7) (treated for $18 \mathrm{~d}$ ) from $\beta$ Carotene solution (treated for only $72 \mathrm{~h}$ ) subjected plants in T3 and T4 (pre- $\beta$-Carotene treatments) to greater stress than plants that were transferred from $\beta$-Carotene solution to Al in T5 and T6 (post- $\beta$ Carotene treatments) (Udengwu and Egedigwe 2014). They explained further that a synergistic effect of both $\mathrm{Al}$ at lower $\mathrm{pH}$ of 4.6 and $\mathrm{H}^{+}$concentration were the real culprits to decreased plant growth.

The responses of $A$. hybridus plants to T6 regarding FWR showed a significant increase in plant growth while for $\mathrm{NOI}$, an insignificant growth in plants was recorded. More so, $\beta$-Carotene significantly ameliorated Al stress for these parameters (NOI and FWR). This shows that the intrinsic antioxidants within plants of $A$. hybridus could not protect them against stress generated from Al toxicity; rather, plants needed a higher dose of $\beta$-Carotene to combat the stress condition. This suggests that under Al stress, the ARE in these plants was increased with higher $\beta$-Carotene concentration. Zhang et al. (2010) found that enzyme activities of amylases and esterases, which decreased the levels of MDA and hydrogen peroxide $\left(\mathrm{H}_{2} \mathrm{O}_{2}\right)$, were increased in wheat plants under stress when pre-treated with $\mathrm{H}_{2} \mathrm{~S}$. In the situation for DWR, only plants that responded to T3 showed a significant increase in plant growth when compared to control and Al treatments. The reason for this is not known, however, there is a possibility that $\beta$ Carotene could play important roles in decreasing the uptake of $A l$ ions because $\beta$-Carotene readily binds to the free hydroxyl groups of Al, forming $\beta$-Carotene -Al complexes (radical adducts and cations), thus reducing free $\mathrm{Al}$ that would have been available for root absorption. It is, therefore, possible that $\beta$ Carotene could have played vital roles in boosting roots mechanisms of either excluding or chelating Al ions. Nevertheless, Al may exhibit an unpredictable interaction with mineral nutrients and $\beta$-Carotene, thus undergoing varying actions in connection with an increase or decrease in concentration when in solution. Al could also affect the secretion or suppression of different hormones that are responsible for different functions in plant growth. The controversy will be whether $\beta$-Carotene interacts with Al in a fashion that up-regulates or down-regulates the production of specific hormones at specific time frames towards the growth of plants. 
Visible symptoms such as leaf stunting, chlorosis and death were characteristic in plants after 9 days of Al treatment. Al could have possibly interfered with essential mineral nutrient uptake in the plants. Some studies have found that Al interference leads to deficiencies of mineral nutrients that consequently manifest symptoms of impaired growth (Delhaize and Ryan 1995; Chang et al. 1999). For all the vegetative and reproductive parameters studied, Al treatment significantly impaired plant growth apart from the FWR, DWR and DWI. It may suggest that plants of $A$. hybridus could have absorbed Al within their leaves, shoots, as well as seeds and there could be a possible transfer of Al, along with the food chain, to its consumers since $A$. hybridus is a staple vegetable source in Sub-Saharan Africa. Though the concentration of Al in different parts of the plant did not form part of this study, studies have shown an increase in the accumulation of $\mathrm{Al}$ and other heavy metals in their shoots and upperparts, inferring that such plants are hyper-metal accumulators without injury to the plants (Kukachka and Miller 1980; Watanabe and Osaki, 2002; Li et al. 2010). Though literal information on the mechanism, cellular localization and chemical form of Al, are meagre; (Jansen et al. (2002) gave reasons for such hyperaccumulative behaviour to either low/non-accumulation of Al in their shoots or an epiphytic habit. Other reasons were differences in soil pH, ectomycorrhizal association, possible acquisition of new Alresponsive mechanisms, and inherited ancestral traits. The present study revealed that the roots were the primary targets of Al toxicity as they were stubby, brittle, brownish and stunted. Similar results have been recorded by other studies (Zhang and Rengel 1999; Mossor-Pietraszewska 2001; Doncheva et al. 2005). Results show that Al stress significantly reduced ROL and that $\beta$-Carotene could not ameliorate the stress condition. This suggests that the apical roots gave rise to an extensive production of lateral roots as a response signal to Al stress. Llugany et al. (2003) showed that plants of Silene armeria responded rapidly by producing many lateral roots following $\mathrm{Cu}$ stress to the root tip meristem. They suggested such responses may prevent the extension of the major root into soil patches with high ion toxicity and favour the extension of lateral roots into the less toxic topsoil. Thus, the production of extensive lateral roots may be responsible for the insignificant increase in plant growth for DWR. Only the response of plants to T3 (pre- $\beta$-Carotene treatment) showed an insignificant ameliorative effect in combating Al stress. A probable reason could be that $\beta$-Carotene boosted roots' exclusion mechanism or exudation of chelating agents in preventing the accumulation of phytotoxic $\mathrm{Al}$ in the apoplast and symplast (Gill and Tuteja 2010).

$\beta$-Carotene and other carotenoids predominantly occur in their all-trans configuration, however, convert to their cis-isomers during its processing or perhaps when in-vivo. It is not known in this study on which isomer was bioavailable to A. hybridus plants, however, studies have shown that the cis-isomers, though susceptible to oxidation and may present lower bioactivity, are more bio-available to humans and animals after processing (Tyssandier et al. 2003; Khoo et al. 2011; Udengwu and Egedigwe 2014; Strati and Oreopoulou 2016). The situation may be different in plants but it is hypothesized in their study that the cis-isomer of lycopene (either in-vitro or in-vivo) ameliorated plants of A. hybridus from Al stress (Udengwu and Egedigwe 2014). This now raises the question whether the cis-isomer is transformed back to its all-trans configuration when in-vivo. 
This study has shown that plants of $A$. hybridus responded positively to supplemented $\beta$-Carotene. Previous studies have concentrated on the roles of $\beta$-Carotene in non-photosynthetic organisms (animal models and humans) because neither animals nor humans can synthesize their antioxidants. Studies concerning the supplementation of in vivo $\beta$-Carotene in plants are meagre; however, studies on $\beta$ Carotene's role in activating and boosting the antioxidant activities of several plants have been reported. Plants' intrinsic antioxidants could be boosted by the application of certain compounds ex vivo or through the induction of stressful conditions. Tian et al. (2012) showed that spermicide alleviated the oxidative damage in cucumber seedlings subjected to high temperatures by enhancing the activities of antioxidant enzymes.

\section{Conclusion}

In conclusion, the present study has shown that under Al stress, plants of $A$. hybridus, 'Inine oma' suffer deteriorating effects if not protected or mitigated with increased concentration of $\beta$-Carotene. An interesting aspect of this work was that plants' fight against Al stress was bolstered by supplemented $\beta$ Carotene. Higher doses of post- $\beta$-Carotene treatment ameliorated Al stress more than other treatments. This is to say that $\beta$-Carotene is not only a precursor of vitamin $A$ but may possess strong anti-oxidative properties against Al toxicity in A. hybridus. Independent $\beta$-Carotene treatments without Al stress that did not significantly affect growth suggested that plants may not require extra antioxidant supplementation unless subjected to Al stress as obtained in pre-and-post- $\beta$-Carotene treatments. From the results, it was evident that plants of $A$. hybridus were not tolerant to Al stress thus, an Al-sensitive plant. This, in turn, could decrease biomass productivity. This study deduces that Al may have interfered with nutrient uptake as well as accumulated in the leaves. Since A. hybridus is a staple vegetable consumed in the SubSaharan region, primary concerns should be to check the transfer of high Al ions to consumers via the food chain. Identification and characterization of specific post- $\beta$-Carotene Al-induced stress genes and their gene products as well as comparing these candidate genes/gene products with other Al-stress related genes/gene products deposited in global databases, will be a promising approach to future research in combating the menace of Al toxicity in Sub-Saharan Africa.

\section{References}

1. Abreu CH, Muraoka T, Lavorante AF (2003) Exchangeable aluminum evaluation in acid soils I Avaliação de alumínio trocável em solos ácidos. Sci Agric 60:543-548. https://doi.org/10.1590/S0103-90162003000300020

2. Aftab T, Khan MMA, Idrees M et al (2010) Stimulation of crop productivity, photosynthesis and artemisinin production in Artemisia annua L. by triacontanol and gibberellic acid application. J Plant Interact 5:273-281. https://doi.org/10.1080/17429141003647137

3. Alak SM, Adams WH (1979) Effects Of Aluminium On Nutrient Composition And Yield Of Oats. J Plant Nutr 1:365-375. https://doi.org/10.1080/01904167909362722 
4. Aslanturk OS, Celik TA (2005) Preventive effect of lycopene on chromosome aberrations in Allium cepa. Pakistan J. of Bio. Sci 8(3):482-486. https://dx.doi.org/10.3923/pjbs.2005.482.486

5. Association of Official Analytical Chemists (2005) Official Methods of Analysis of AOAC International (18th Ed.). Gaithersburg, Maryland, USA. 983 pp

6. Baltschun D, Beutner S, Briviba K et al (1997) Singlet oxygen quenching abilities of carotenoids. Liebigs Ann 1887-1893. https://doi.org/10.1002/jlac.199719970913

7. Bendich A (1989) Carotenoids and the immune response. J Nutr 119:112-115. https://doi.org/10.1093/jn/119.1.112

8. Bera S, De AK, Adak MK (2019) Modulation of Glycine Betaine Accumulation with Oxidative Stress Induced by Aluminium Toxicity in Rice. Proc Natl Acad Sci India Sect B - Biol Sci 89:291-301. https://doi.org/10.1007/s40011-017-0948-7

9. Bhalerao SA, Prabhu DV (2013) Aluminium toxicity in plants: a review. J Appl Chem 2:447-474

10. Blue WG, Dantzman CL (1977) Soil chemistry and root development in acid soils. Proc. Soil Crop Sci. Soc. Fla. 36: 9-15

11. Boscolo PRS, Menossi M, Jorge RA (2003) Aluminum-induced oxidative stress in maize. Phytochemistry 62:181-189. https://doi.org/10.1016/S0031-9422(02)00491-0

12. Bojórquez-Quintal E, Escalante-Magaña C, Echevarría-Machado I, Martínez-Estévez M (2017) Aluminum, a friend or foe of higher plants in acid soils. Front Plant Sci 8:1-18. https://doi.org/10.3389/fpls.2017.01767

13. Bose J, Babourina O, Rengel Z (2011) Role of magnesium in alleviation of aluminium toxicity in plants. J Exp Bot 62:2251-2264. https://doi.org/10.1093/jxb/erq456

14. Chang YC, Yamamoto $Y$, Matsumoto $H$ (1999) Accumulation of aluminium in the cell wall pectin in cultured tobacco (Nicotiana tabacum L.) cells treated with a combination of aluminium and iron. Plant Cell Environ 22:1009-1017. https://doi.org/10.1046/j.1365-3040.1999.00467.x

15. Darkó É, Ambrus H, Stefanovits-Bányai É et al (2004) Aluminium toxicity, Al tolerance and oxidative stress in an Al-sensitive wheat genotype and in Al-tolerant lines developed by in vitro microspore selection. Plant Sci 166:583-591. https://doi.org/10.1016/j.plantsci.2003.10.023

16. De Carvalho MM, Andrew CS, Edwards DG, Asher CJ (1980) Comparative performance of six Stylosanthes species in three acid soils. Aust J Agric Res 31:61-76. https://doi.org/10.1071/AR9800061

17. Delhaize E, Ryan PR (1995) Aluminium toxicity and tolerance in plants. Plant Physiol 107:315-321. https://doi.org/10.1104/pp.107.2.315

18. Devi SS, Saha B, Panda SK (2020) Differential loss of ROS homeostasis and activation of antioxidative defence response in tea cultivar due to aluminium toxicity in acidic soil. Curr Trends Biotechnol Pharm 14:33-43. https://doi.org/10.5530/ctbp.2020.1.3

19. Di Mascio P, Kaiser S, Sies H (1989) Lycopene as the most efficient biological carotenoid singlet oxygen quencher. Arch Biochem Biophys 274:532-538. https://doi.org/10.1016/0003- 
9861(89)90467-0

20. Dickson W (1978) Some effects of the acidification of Swedish lakes. SIL Proceedings, 1922-2010 20:851-856. https://doi.org/10.1080/03680770.1977.11896609

21. Doncheva S, Amenós M, Poschenrieder C, Barceló J (2005) Root cell patterning: A primary target for aluminium toxicity in maize. J Exp Bot 56:1213-1220. https://doi.org/10.1093/jxb/eri115

22. Esrefoglu M, Akinci A, Taslidere E et al (2016) Ascorbic acid and beta-carotene reduce stress-induced oxidative organ damage in rats. Biotech Histochem 91:455-464.

https://doi.org/10.1080/10520295.2016.1220019

23. Fatur T, Tušek M, Falnoga I et al (2002) DNA damage and metallothionein synthesis in human hepatoma cells (HepG2) exposed to cadmium. Food Chem Toxicol 40:1069-1076. https://doi.org/10.1016/S0278-6915(02)00058-3

24. Fiskesjo G (1981) The Allium test as a standard in environmental monitoring. Hereditas 102:99-112. https://doi.org/10.1111/j.1601-5223.1985.tb00471.x

25. Foy CD, Duke JA, Devine TE (1992) Tolerance of soybean germplasm to an acid tatum subsoil. J Plant Nutr 15:527-547. https://doi.org/10.1080/01904169209364339

26. Foy CD, Fleming AL (1982) Aluminum tolerances of two wheat genotypes related to nitrate reductase activities. J Plant Nutr 5:1313-1333. https://doi.org/10.1080/01904168209363064

27. Gill SS, Tuteja N (2010) Reactive oxygen species and antioxidant machinery in abiotic stress tolerance in crop plants. Plant Physiol Biochem 48:909-930.

https://doi.org/10.1016/j.plaphy.2010.08.016

28. Giuliano AE, Connolly JL, Edge SB et al (2017) Breast Cancer-Major changes in the American Joint Committee on Cancer eighth edition cancer staging manual. CA Cancer J Clin 67:290-303. https://doi.org/10.3322/caac.21393

29. Gupta N, Gaurav SS, Kumar A (2013) Molecular Basis of Aluminium Toxicity in Plants: A Review. Am J Plant Sci 04:21-37. https://doi.org/10.4236/ajps.2013.412a3004

30. Hanachi P, Sh G (2009) Using HPLC to determine the composition and antioxidant activity of Berberis vulgaris. Eur J Sci Res 29:47-54

31. Harris WR, Berthon G, Day JP et al (1996) Speciation of aluminium in biological systems. J Toxicol Environ Health 48:543-568. https://doi.org/10.1080/009841096161069

32. He H, He L, Gu M (2014) Role of microRNAs in aluminium stress in plants. Plant Cell Rep 33:831836. https://doi.org/10.1007/s00299-014-1565-z

33. Hede AR, Skovmand B, Lopez-Csati J (2001) Acid soils and aluminium toxicity. In: Reynolds MP, Ortiz-Monasterio JI, McNab A (eds) Application of physiology in wheat breeding. D.F. CIMMYT, Mexico, pp 172-182

34. Hoagland DR, Arnon DI (1950) The water-culture method for growing plants without soil. California Agricultural Experiment Station Circular 347:1-32 
35. Horst WJ, Wang Y, Eticha D (2010) REVIEW: PART OF A HIGHLIGHT SECTION ON PLANT-SOIL INTERACTIONS AT LOW PH The role of the root apoplast in aluminium-induced inhibition of root elongation and in aluminium resistance of plants: a review. Ann. Bot. https://doi.org/10.1093/aob/mcq053

36. Inostroza-Blancheteau C, Renge Z, Alberdi M et al (2012) Molecular and physiological strategies to increase aluminium resistance in plants. Mol Biol Rep 39:2069-2079.

https://doi.org/10.1007/s11033-011-0954-4

37. Jansen S, Watanabe T, Smets E (2002) Aluminium accumulation in leaves of 127 species in Melastomataceae, with comments on the order Myrtales. Ann Bot 90:53-64. https://doi.org/10.1093/aob/mcf142

38. Jaskowiak J, Kwasniewska J, Milewska-Hendel A et al (2019) Aluminum alters the histology and pectin cell wall composition of barley roots. Int J Mol Sci 20:1-18.

https://doi.org/10.3390/ijms20123039

39. Jones DL, Blancaflor EB, Kochian LV, Gilroy \& S (2006) Spatial dynamics of Al, ROS and callose in maize roots Spatial coordination of aluminium uptake, production of reactive oxygen species, callose production and wall rigidification in maize roots. Plant Cell Environ 29:1309-1318. https://doi.org/10.1111/j.1365-3040.2006.01509.x

40. Khoo HE, Prasad KN, Kong KW et al (2011) Carotenoids and their isomers: Color pigments in fruits and vegetables. Molecules 16:1710-1738. https://doi.org/10.3390/molecules16021710

41. Kinraide TB (1990) Assessing the rhizotoxicity of the aluminate ion, $\mathrm{Al}(\mathrm{OH})^{4-}$. Plant Physiol 93:1620-1625. https://doi.org/10.1104/pp.93.4.1620

42. Kochian LV (1995) Cellular mechanisms of aluminium toxicity and resistance in plants. Annu Rev Plant Physiol Plant Mol Biol 46:237-260. https://doi.org/10.1146/annurev.pp.46.060195.001321

43. Kochian LV, Piñeros MA, Liu J, Magalhaes JV (2015) Plant adaptation to acid soils: The molecular basis for crop aluminum resistance. Annu Rev Plant Biol 66:571-598.

https://doi.org/10.1146/annurev-arplant-043014-114822

44. Kopittke PM, Moore KL, Lombi E et al (2015) Identification of the primary lesion of toxic aluminium in plant roots. Plant Physiol 167:1402-1411. https://doi.org/10.1104/pp.114.253229

45. Kukachka BF, Miller RB (1980) A chemical spot-test for aluminium and its value in wood identification. Inter Assoc Wood Anatomist Bulletin New Series 1:104-109. https://doi.org/10.1163/22941932-90000699

46. Lemmens L, De Vleeschouwer K, Moelants KRN et al (2010) $\beta$-Carotene isomerization kinetics during thermal treatments of carrot puree. J Agric Food Chem 58:6816-6824. https://doi.org/10.1021/jf100449t

47. Li QS, Cai SS, Mo CH et al (2010) Toxic effects of heavy metals and their accumulation in vegetables grown in saline soil. Ecotoxicol Environ Saf 73:84-88. https://doi.org/10.1016/j.ecoenv.2009.09.002

48. Llugany M, Lombini A, Poschenrieder C, Barcelo J (2003) Different mechanisms account for enhanced copper resistance in Silene armeria ecotypes from mine spoils and serpentine sites. Plt soil 
251:55-63. http://doi.org/10.1023/A:1022990525632

49. Ma JF, Ryan PR, Delhaize E (2001) Aluminium tolerance in plants and the complexing role of organic acids. Trends Plant Sci 6:273-278. https://doi.org/10.1016/S1360-1385(01)01961-6

50. Miller NJ, Sampson J, Candeias LP et al (1996) Antioxidant Properties of Carotenes and Xanthophylls. FEBS Lett 384:240-242

51. Moore DP (1974) Physiological effects of pH on roots. In: The plant root and the environment (Ed.) Carson EW. University Press of Virginia, Charlottesville 135-151

52. Moran NA, Jarvik T (2010) Lateral transfer of genes from fungi underlies carotenoid production in aphids. Science 328:624-627. https://doi.org/10.1126/science.1187113

53. Mossor-Pietraszewska T (2001) Effect of aluminium on plant growth and metabolism. Acta Biochim Pol 48:673-686. https://doi.org/10.18388/abp.2001_3902

54. Mueller L, Boehm V (2011) Antioxidant activity of $\beta$-carotene compounds in different in vitro assays. Molecules 16:1055-1069. https://doi.org/10.3390/molecules16021055

55. Nezames CD, Sjogren CA, Barajas JF, Larsen PB (2012) The Arabidopsis cell cycle checkpoint regulators TANMEI/ALT2 and ATR mediate the active process of aluminium-dependent root growth inhibition. Plant Cell 24:608-621. https://doi.org/10.1105/tpc.112.095596

56. Nunes-Nesi A, Brito DS, Inostroza-Blancheteau C et al (2014) The complex role of mitochondrial metabolism in plant aluminium resistance. Trends Plant Sci 19:399-407. https://doi.org/10.1016/j.tplants.2013.12.006

57. Osaki M, Watanabe T, Tadano T (1997) Beneficial effect of aluminium on growth of plants adapted to low ph soils. Soil Sci Plant Nutr 43:551-563. https://doi.org/10.1080/00380768.1997.10414782

58. Palani K, Balasubramanian K, Kalaivani RA (2018) Study on Aluminium Contamination in Mettur Soil and its Subsequent Uptake by Medicinal Plants. Orient J Chem 34:3129-3133. https://doi.org/10.13005/ojc/340659

59. Peters JL, Castillo FJ, Heath RL (1989) Alteration of extracellular enzymes in pinto bean leaves upon exposure to air pollutants, ozone and sulfur dioxide. Plant Physiol 89:159-164. https://doi.org/10.1104/pp.89.1.159

60. Pournourmohammadi S, Khazaeli P, Eslamizad S et al (2008) Study on the oxidative stress status among cement plant workers. Hum Exp Toxicol 27:463-469. https://doi.org/10.1177/0960327108094956

61. Rahman R, Upadhyaya $\mathrm{H}$ (2021) Aluminium toxicity and its tolerance in plant: A review. J Plant Biol 64:101-121. https://doi.org/10.1007/s12374-020-09280-4

62. Rao AV, Rao LG (2007) Carotenoids and human health. Pharmacol Res 55:207-216. https://doi.org/10.1016/j.phrs.2007.01.012

63. Rengel Z, Bose J, Chen Q, Tripathi BN (2015) Magnesium alleviates plant toxicity of aluminium and heavy metals. Crop Pasture Sci 66:1298-1307. https://doi.org/10.1071/CP15284 
64. Rhee KS (1978) Minimization of further lipid peroxidation in the distillation 2-thiobarbituric acid test of fish and meat. J Food Sci 43:1776-1778. https://doi.org/10.1111/j.1365-2621.1978.tb07411.x

65. Rincón M, Gonzales RA (1992) Aluminum Partitioning in Intact Roots of Aluminum-. Plant Physiol 3:1021-1028

66. Rosmaninho LB, de C, Dias, Silva LAS MF da, et al (2019) Performance of Crambe Submitted to Aluminum Stress: An Important Oilseed Plant. J Agric Sci 11:454.

https://doi.org/10.5539/jas.v11n2p454

67. Rouphael Y, Rea E, Cardarelli M et al (2016) Can adverse effects of acidity and aluminium toxicity be alleviated by appropriate rootstock selection in cucumber? Front Plant Sci 7:1-12. https://doi.org/10.3389/fpls.2016.01283

68. Rout G, Samantaray S, Das $P$ et al (2001) Aluminium toxicity in plants: a review To cite this version: HAL Id: Hal-00886101 Aluminium toxicity in plants: a review. Agronomie 21:3-21

69. Samac DA, Tesfaye M (2003) Plant improvement for tolerance to aluminium in acid soils - A review. Plant Cell Tissue Organ Cult 75:189-207. https://doi.org/10.1023/A:1025843829545

70. Samardakiewicz S, Woźny A (2005) Cell division in Lemna minor roots treated with lead. Aquat Bot 83:289-295. https://doi.org/10.1016/j.aquabot.2005.06.007

71. Savvas D, Colla G, Rouphael Y, Schwarz D (2010) Amelioration of heavy metal and nutrient stress in fruit vegetables by grafting. Sci Hortic (Amsterdam) 127:156-161.

https://doi.org/10.1016/j.scienta.2010.09.011

72. Schmitt M, Watanabe T, Jansen S (2016) The effects of aluminium on plant growth in a temperate and deciduous aluminium accumulating species. AoB Plants 8.

https://doi.org/10.1093/aobpla/plw065

73. Seguel A, Cumming JR, Klugh-Stewart K et al (2013) The role of arbuscular mycorrhizas in decreasing aluminium phytotoxicity in acidic soils: A review. Mycorrhiza 23:167-183. https://doi.org/10.1007/s00572-013-0479-x

74. Shahnawaz M, Sanadhya D (2019) Aluminium Induced Oxidative Stress and Antioxidants System in Two Barley Varieties and Its Alleviation Through Ascorbic Acid and Salicylic Acid Seed Priming Approach. Int J Life Sci Pharma Res 7:26-37

75. Sharma P, Dubey RS (2007) Involvement of oxidative stress and role of antioxidative defence system in growing rice seedlings exposed to toxic concentrations of aluminium. Plant Cell Rep 26:20272038. https://doi.org/10.1007/s00299-007-0416-6

76. Shull KE (1960) Suggested modified aluminon method for aluminium determination. J Am Water Works Assoc 52(6):779-785. https://doi.org/10.1002/j.1551-8833.1960.tb00532.x

77. Siecinska J, Nosalewicz A (2017) Aluminium Toxicity to Plants as Influenced by the Properties of the Root Growth Environment Affected by Other Co-Stressors: A Review. Rev Environ Contam Toxicol 126. https://doi.org/10.1007/398_2016_15

78. Silva S (2012) Aluminium Toxicity Targets in Plants. J Bot 2012:1-8. https://doi.org/10.1155/2012/219462 
79. Singh S, Tripathi DK, Singh S et al (2017) Toxicity of aluminium on various levels of plant cells and organism: A review. Environ Exp Bot 137:177-193. https://doi.org/10.1016/j.envexpbot.2017.01.005

80. Soto-Cerda BJ, Inostroza-Blancheteau C, Mathías M et al (2015) Marker-assisted breeding for TaALMT1, a major gene conferring aluminium tolerance to wheat. Biol Plant 59:83-91. https://doi.org/10.1007/s10535-014-0474-x

81. Stahl W, Sies H (2003) Antioxidant activity of carotenoids. Mol Aspects Med 24:345-351. https://doi.org/10.1016/S0098-2997(03)00030-X

82. Stephenson FH (2010) Solutions, mixtures and media. In: Calculations for molecular biology and biotechnology; A guide to mathematics in the laboratory (Second Edition). Academic Press San Diego, CA 92101 - 4495 USA. 460pp

83. Strati IF, Oreopoulou V (2016) Recovery and Isomerization of Carotenoids from Tomato Processing By-products. Waste Biomass Valoriz 7:843-850. https://doi.org/10.1007/s12649-016-9535-z

84. Tamás L, Huttová J, Mistrík I et al (2006) Aluminium-induced drought and oxidative stress in barley roots. J Plant Physiol 163:781-784. https://doi.org/10.1016/j.jplph.2005.08.012

85. Tian J, Wang LP, Yang YJ et al (2012) Exogenous spermidine alleviates the oxidative damage in cucumber seedlings subjected to high temperatures. J Am Soc Hortic Sci 137:11-19. https://doi.org/10.21273/jashs.137.1.11

86. Tyssandier V, Reboul E, Dumas JF et al (2003) Processing of vegetable-borne carotenoids in the human stomach and duodenum. Am J Physiol - Gastrointest Liver Physiol 284. https://doi.org/10.1152/ajpgi.00410.2002

87. Udengwu OS, Egedigwe UO (2014) Effects of lycopene on hydroponic growth and productivity of Amaranthus hybridus L. under Aluminium Toxicity Induced Stress. Afr J Biotech 13(49):4476-4491. https://doi.org/10.5897/AJB2014.13692

88. Vasconcelos CV, Costa AC, Müller C et al (2020) Potential of calcium nitrate to mitigate the aluminium toxicity in Phaseolus vulgaris: effects on morphoanatomical traits, mineral nutrition and photosynthesis. Ecotoxicology 29:203-216. https://doi.org/10.1007/s10646-020-02168-6

89. Wagatsuma T, Kaneko M, Hayasaka Y (1987) Destruction process of plant root cells by aluminium. Soil Sci Plant Nutr 33:161-175. https://doi.org/10.1080/00380768.1987.10557563

90. Wierzbicka M (1988) Mitotic disturbances induced by low doses of inorganic lead. Caryologia 41:143-160. https://doi.org/10.1080/00087114.1988.10797856

91. Wierzbicka M (1989) Disturbances in cytokinesis caused by inorganic lead. Environ Exp Bot 29:123133. https://doi.org/10.1016/0098-8472(89)90044-0

92. Woodall AA, Britton G, Jackson MJ (1997) Carotenoids and protection of phospholipids in solution or in liposomes against oxidation by peroxyl radicals: Relationship between carotenoid structure and protective ability. Biochim Biophys Acta - Gen Subj 1336:575-586. https://doi.org/10.1016/S03044165(97)00007-X

93. Yang M, Tan L, Xu Y et al (2015) Effect of low pH and aluminium toxicity on the photosynthetic characteristics of different fast-growing Eucalyptus vegetatively propagated clones. PLoS One 10:1- 
15. https://doi.org/10.1371/journal.pone.0130963

94. Yaping Z, Suping Q, Wenli Y et al (2002) Antioxidant activity of lycopene extracted from tomato paste towards trichloromethyl peroxyl radical CCl302. Food Chem 77:209-212. https://doi.org/10.1016/S0308-8146(01)00339-9

95. Zhang H, Jiang Z, Qin R et al (2014) Accumulation and cellular toxicity of aluminium in seedling of Pinus massoniana. BMC Plant Biol 14:1-16. https://doi.org/10.1186/s12870-014-0264-9

96. Zhang H, Tan ZQ, Hu LY et al (2010) Hydrogen Sulfide Alleviates Aluminum Toxicity in Germinating Wheat Seedlings. J Integr Plant Biol 52:556-567. https://doi.org/10.1111/j.1744-7909.2010.00946.x

97. Zhang WH, Rengel Z (1999) Aluminium induces an increase in cytoplasmic calcium in intact wheat root apical cells. Aust J Plant Physiol 26:401-409. https://doi.org/10.1071/PP98149

\section{Figures}

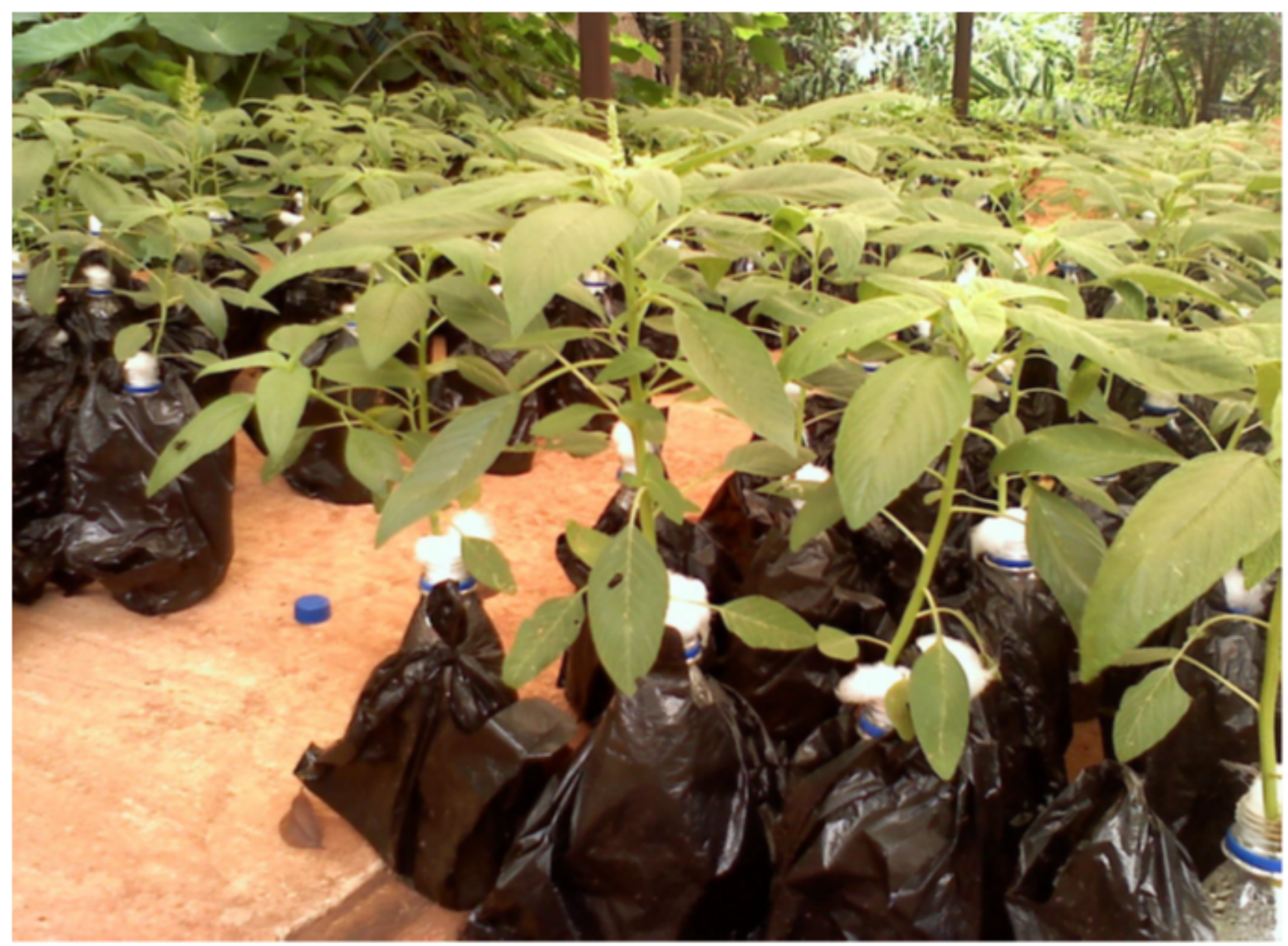

Figure 1

Growth of Amaranthus hybridus plants in hydroponics 


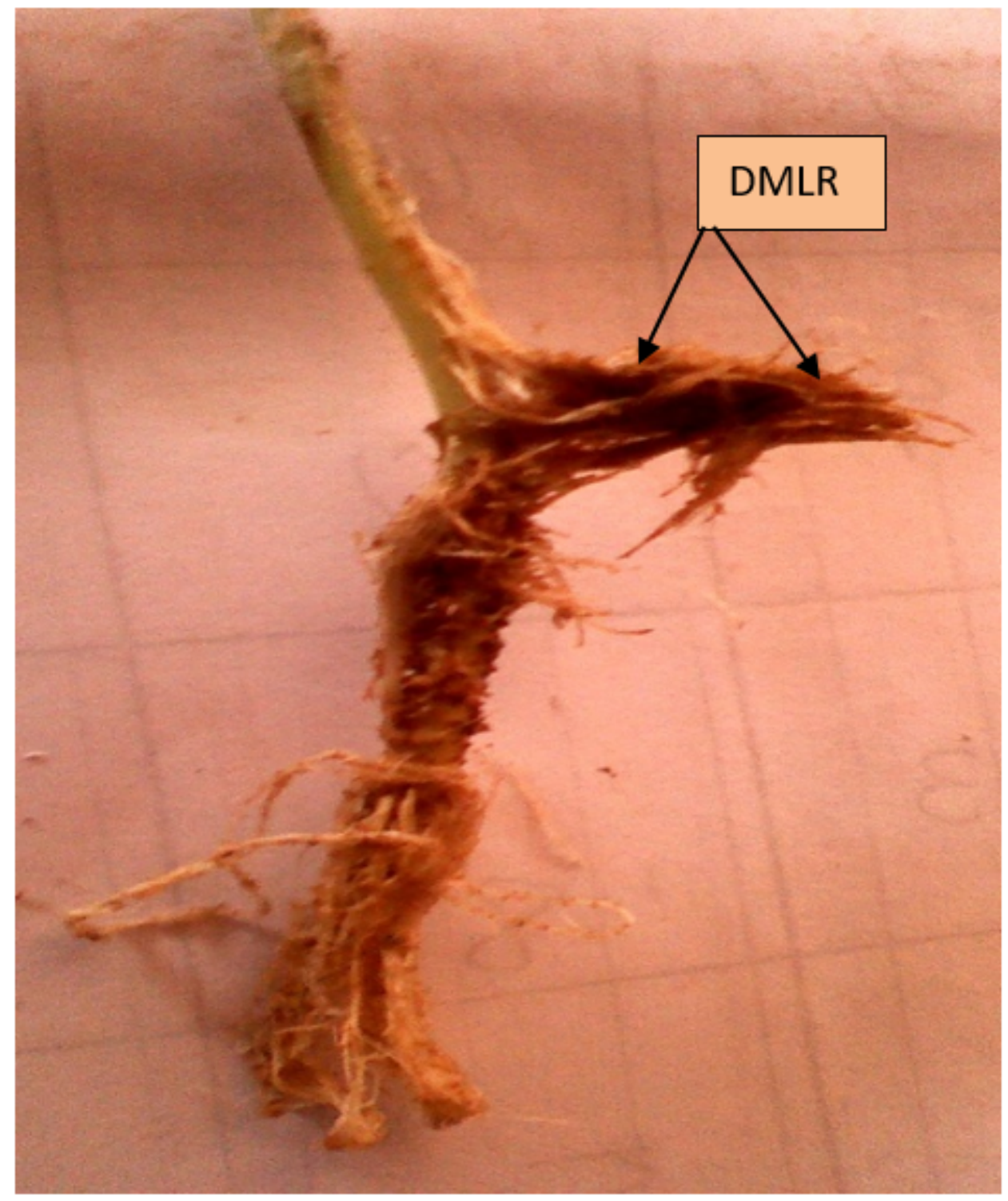

Figure 2

Roots of Al toxicity stressed normal plant enlarged. DMLR=dense mesh of lateral roots (Udengwu and Egedigwe 2014) 


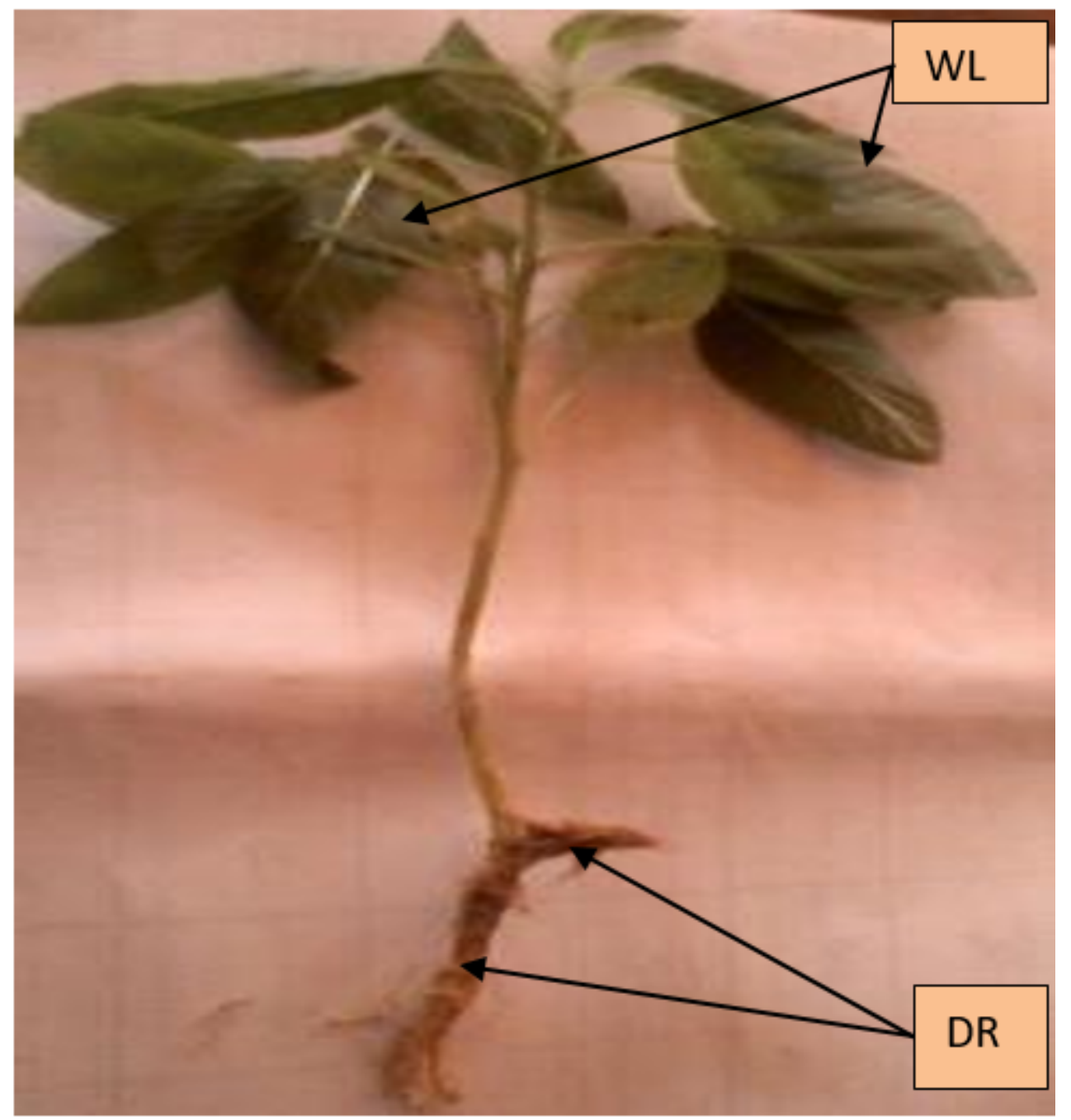

Figure 3

Aluminium toxicity stressed plant WL=Wilting of leaves; DR=Damaged roots (Udengwu and Egedigwe 2014) 


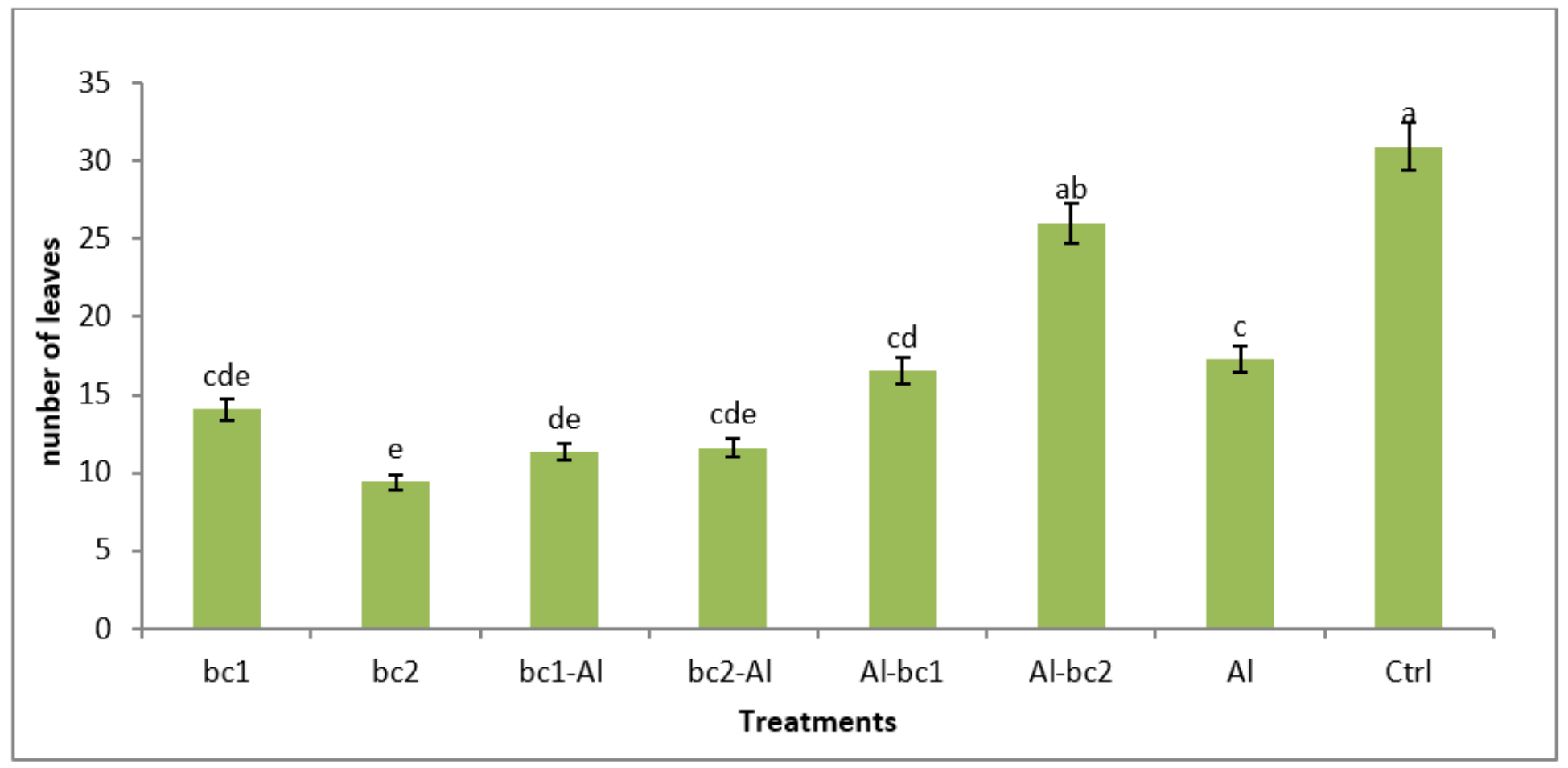

Figure 4

Effects of treatments on the number of leaves (NOL). *Bars bearing different letters differ significantly $(\mathrm{LSD} \leq 0.05)$

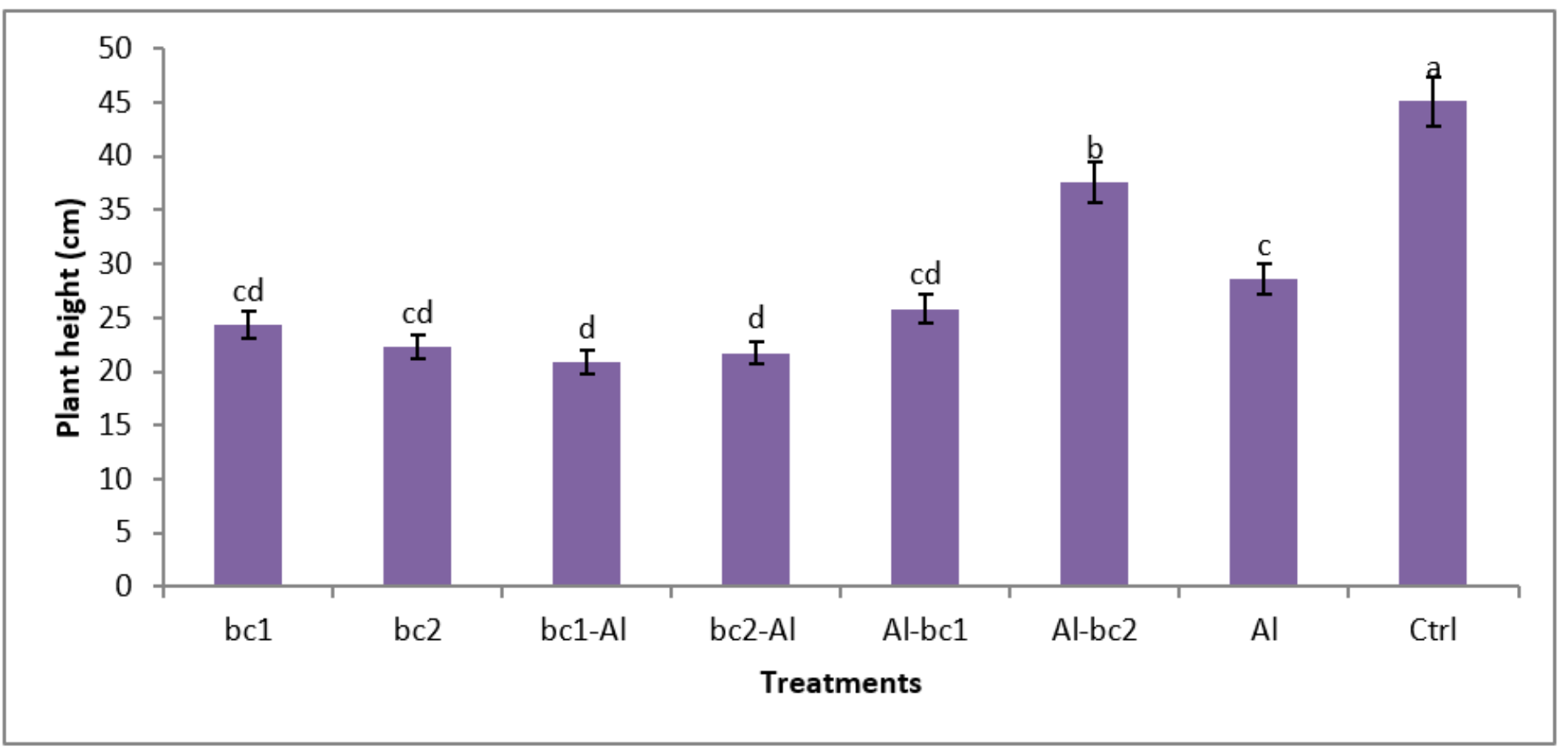

Figure 5

Effects of treatments on plant height (PLH). *Bars bearing different letters differ significantly (LSD $\leq$ $0.05)$ 


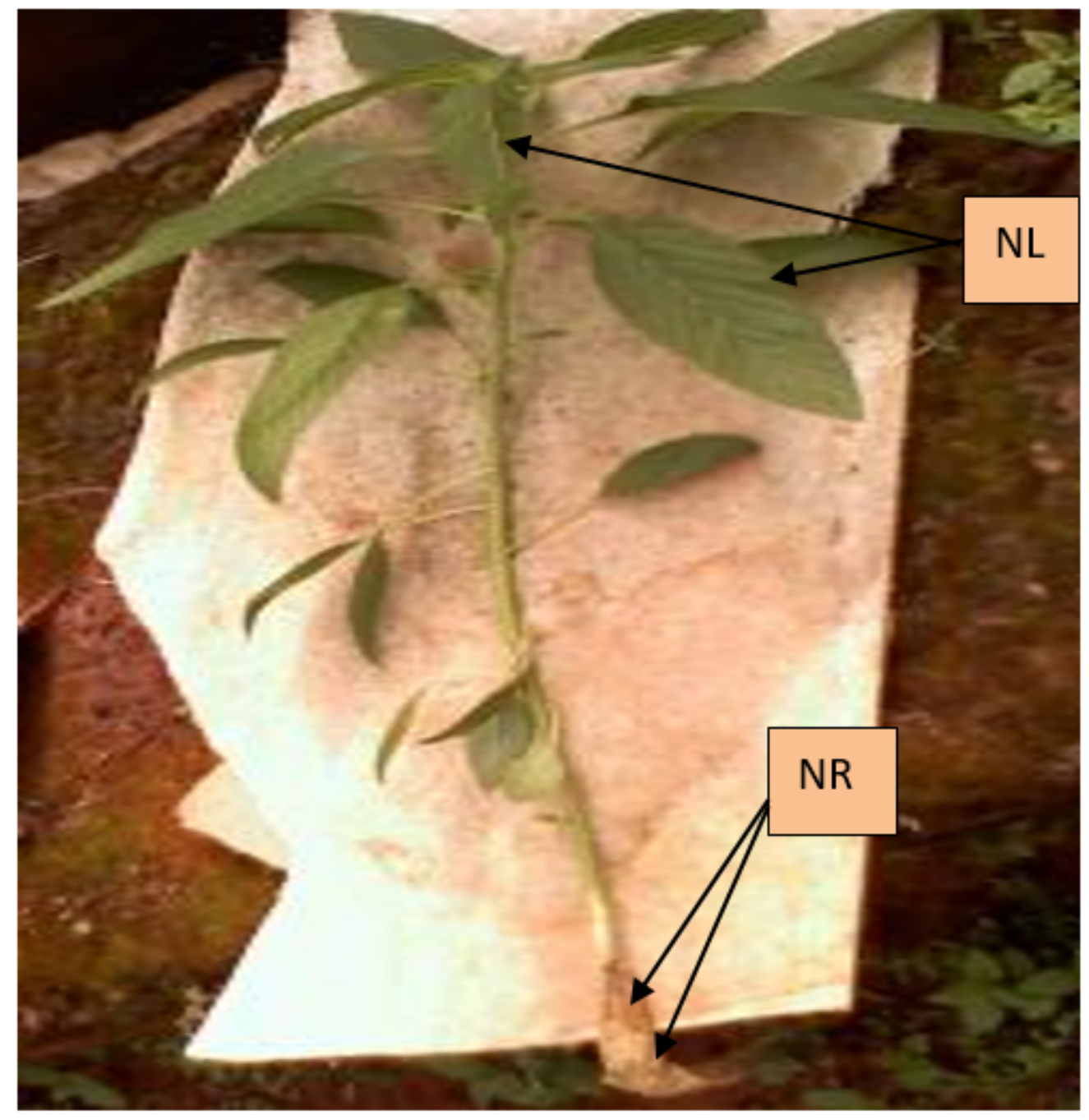

Figure 6

Control Amaranthus plant NL=Normal leaves; NR=normal roots (Udengwu and Egedigwe 2014) 


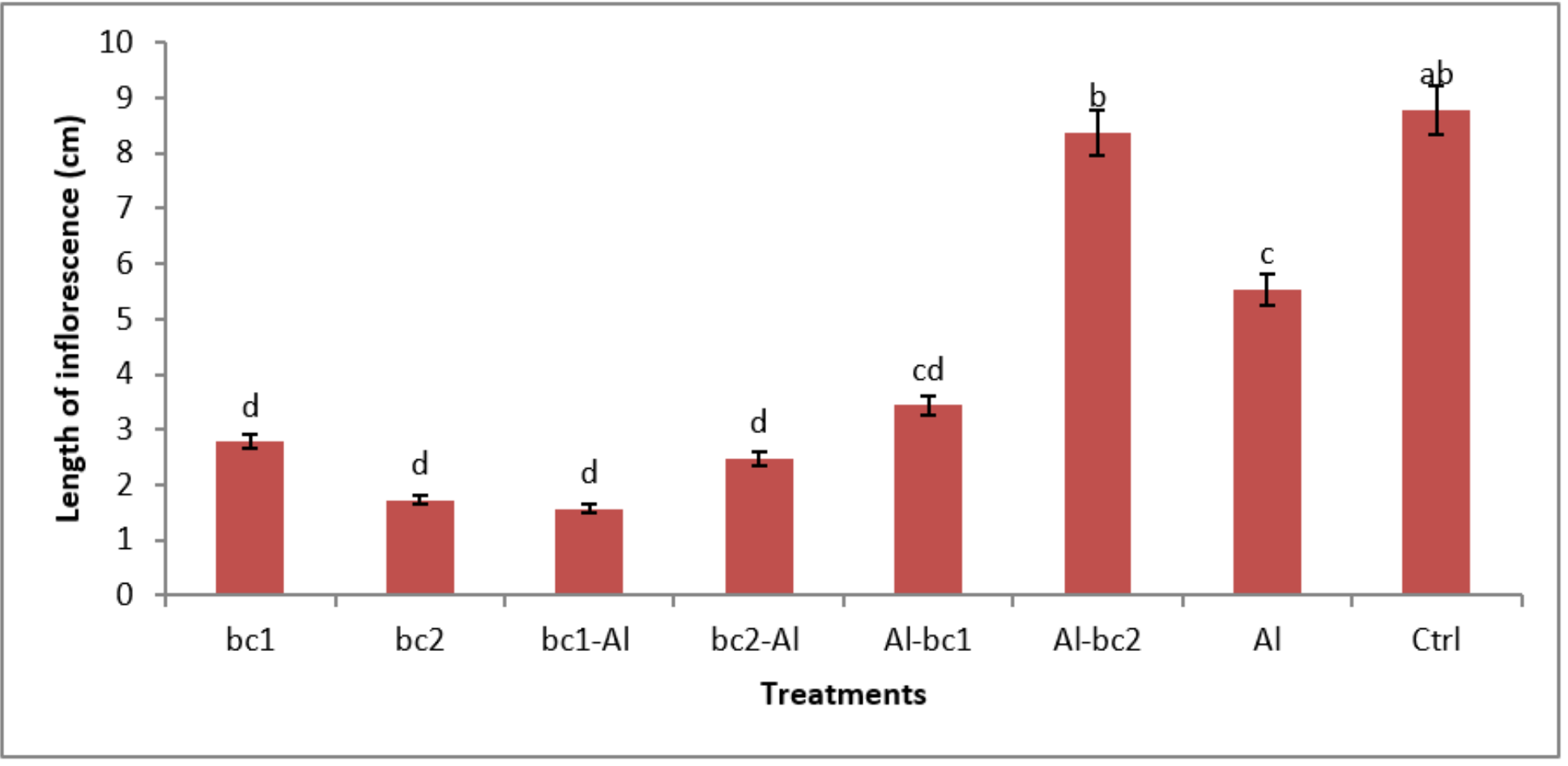

Figure 7

Effects of treatments on the length of inflorescence (LOI). *Bars bearing different letters differ significantly $(\mathrm{LSD} \leq 0.05)$

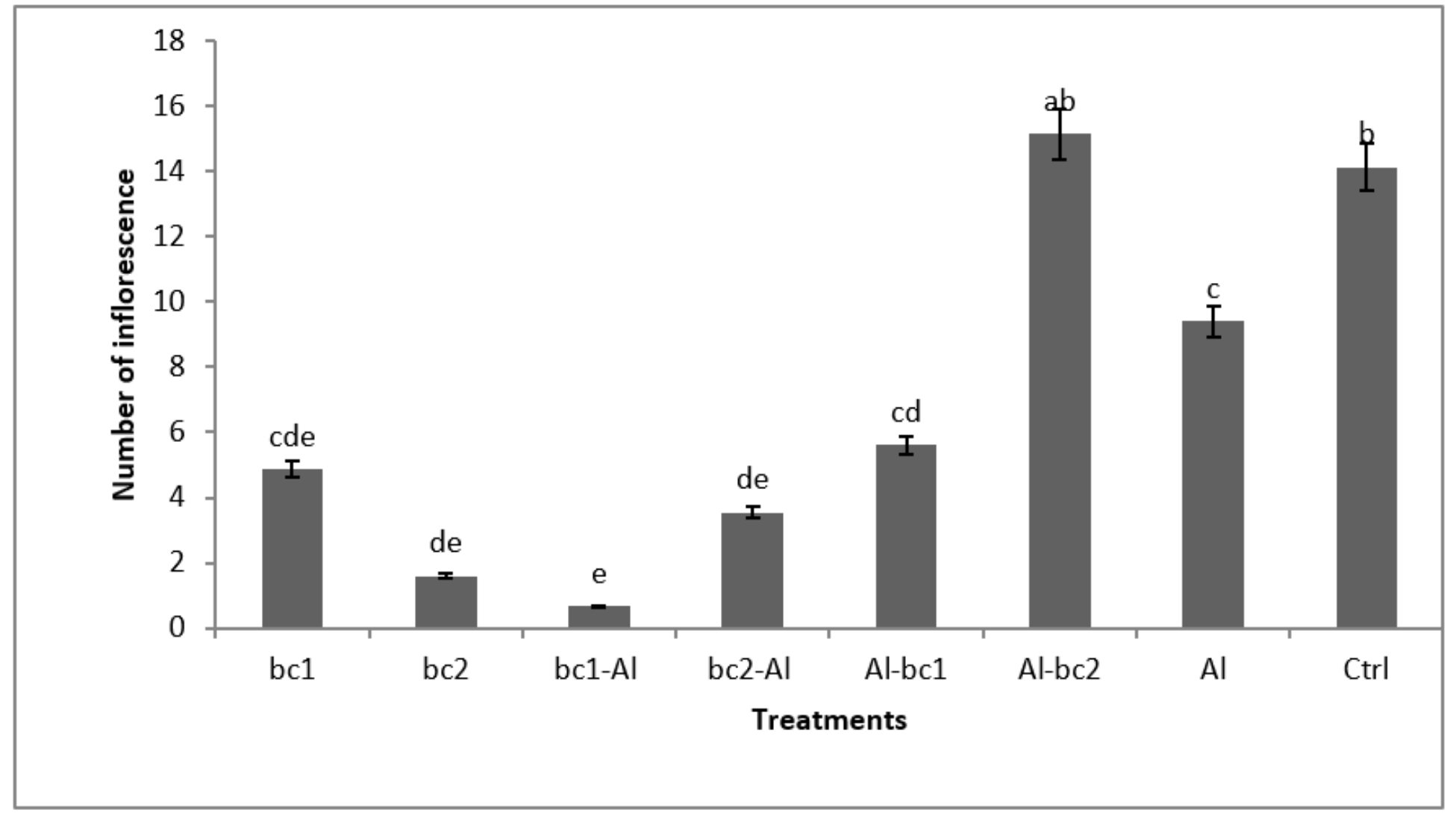

Figure 8 
Effects of treatments on the number of inflorescences (NOI). *Bars bearing different letters differ significantly (LSD $\leq 0.05)$

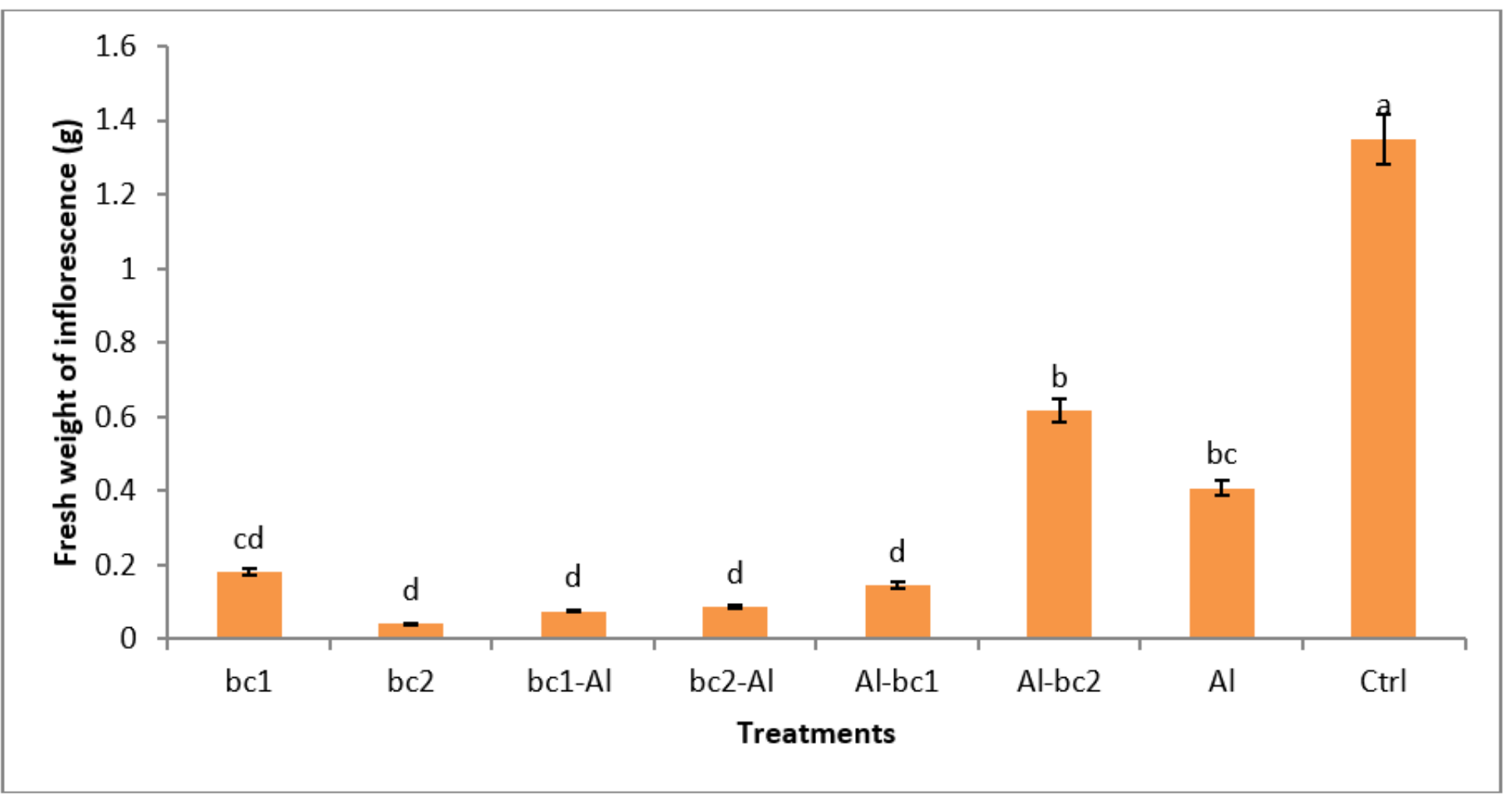

Figure 9

Effects of treatments on fresh weight of inflorescence (FWI). *Bars bearing different letters differ significantly $(\mathrm{LSD} \leq 0.05)$

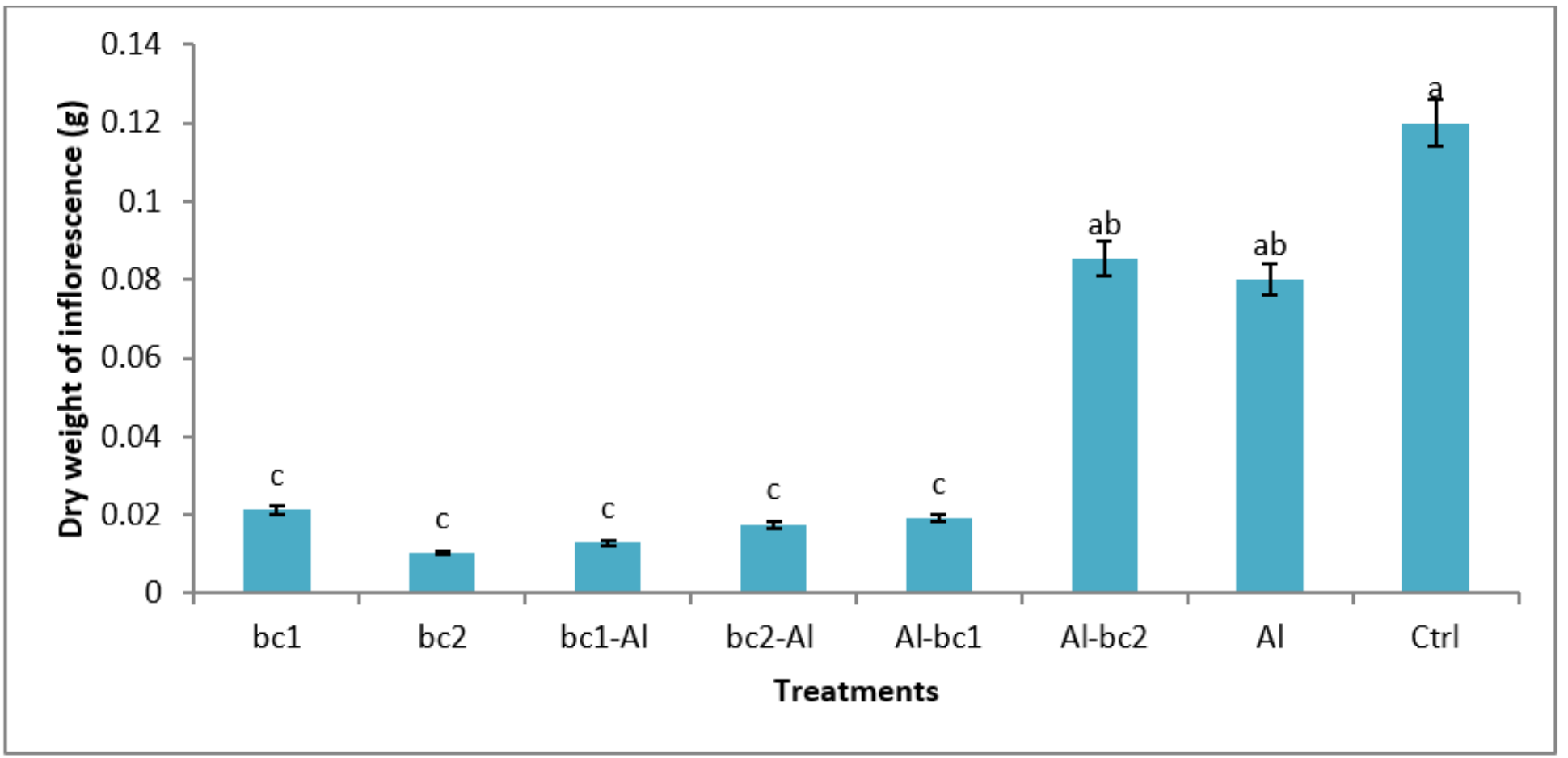

Figure 10 
Effects of treatments on the dry weight of inflorescence (DWI). *Bars bearing different letters differ significantly (LSD $\leq 0.05)$

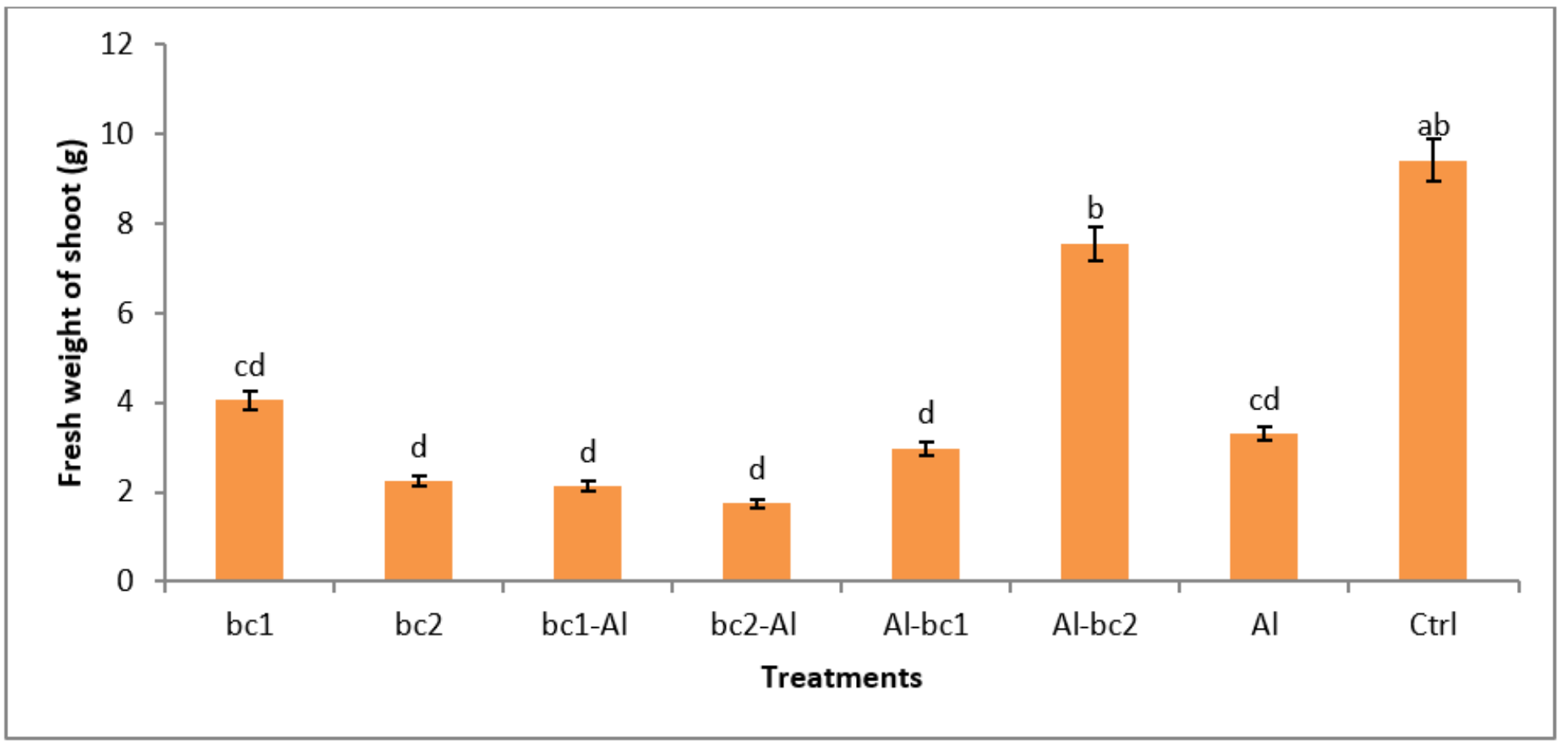

\section{Figure 11}

Effects of treatments on fresh weight of shoot (FWI). *Bars bearing different letters differ significantly $(\mathrm{LSD} \leq 0.05)$

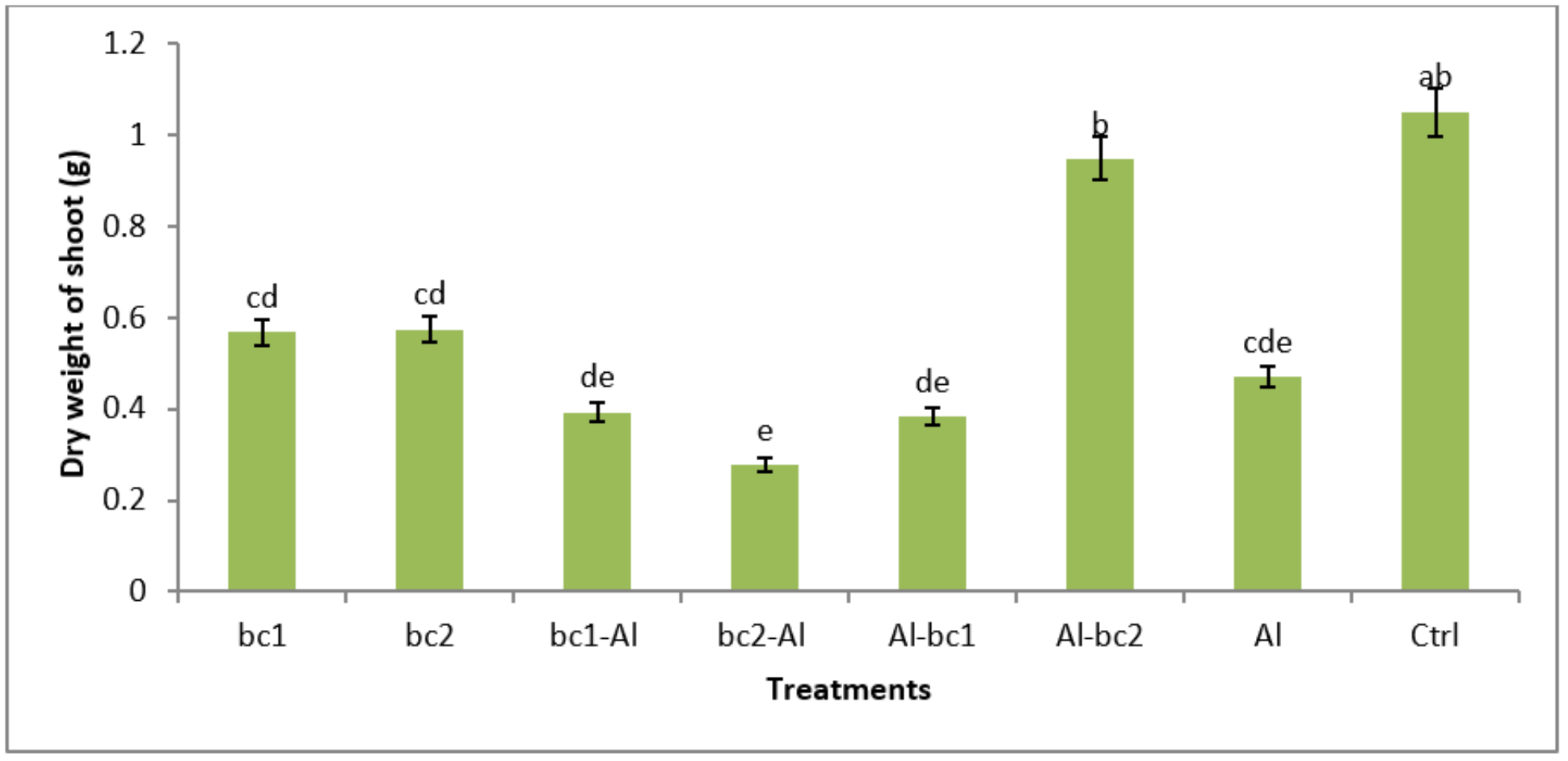

Figure 12 
Effects of treatments on the dry weight of shoot (DWS). *Bars bearing different letters differ significantly $(\mathrm{LSD} \leq 0.05)$

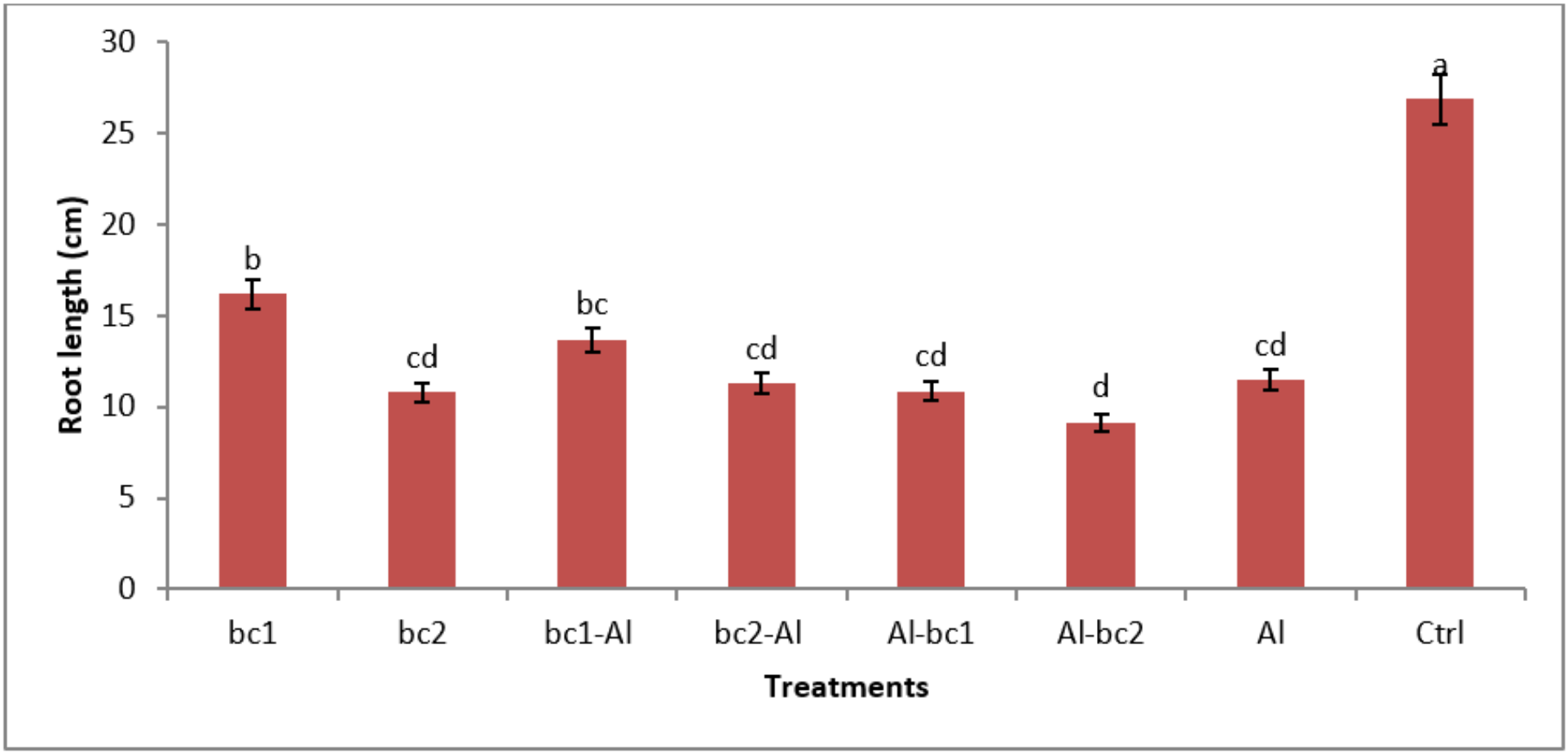

Figure 13

Effects of treatments on root length (ROL). *Bars bearing different letters differ significantly (LSD $\leq 0.05)$ 


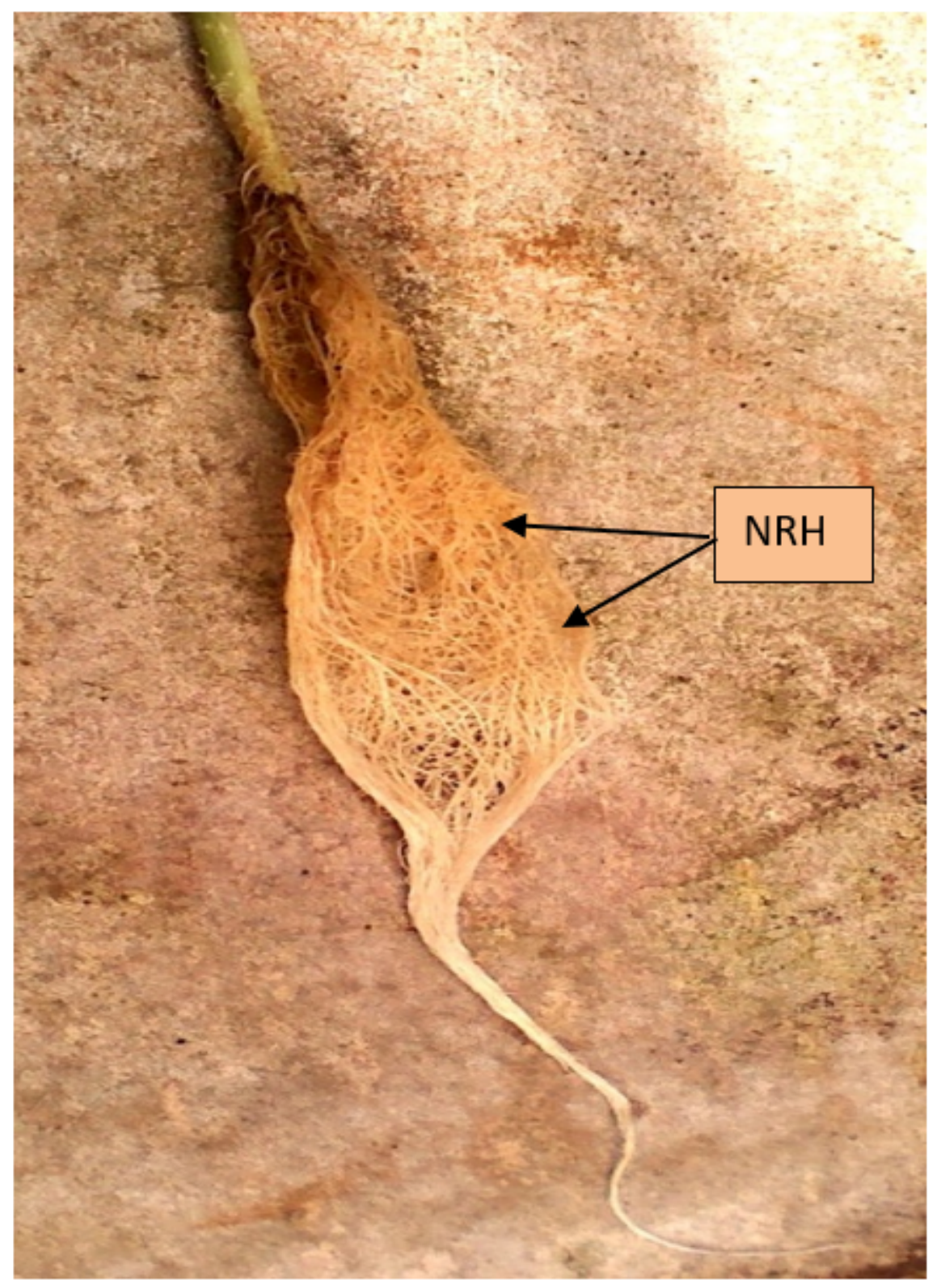

\section{Figure 14}

Roots of control plant enlarged. NRH=Normal Roots from Hydroponics (Udengwu and Egedigwe 2014) 


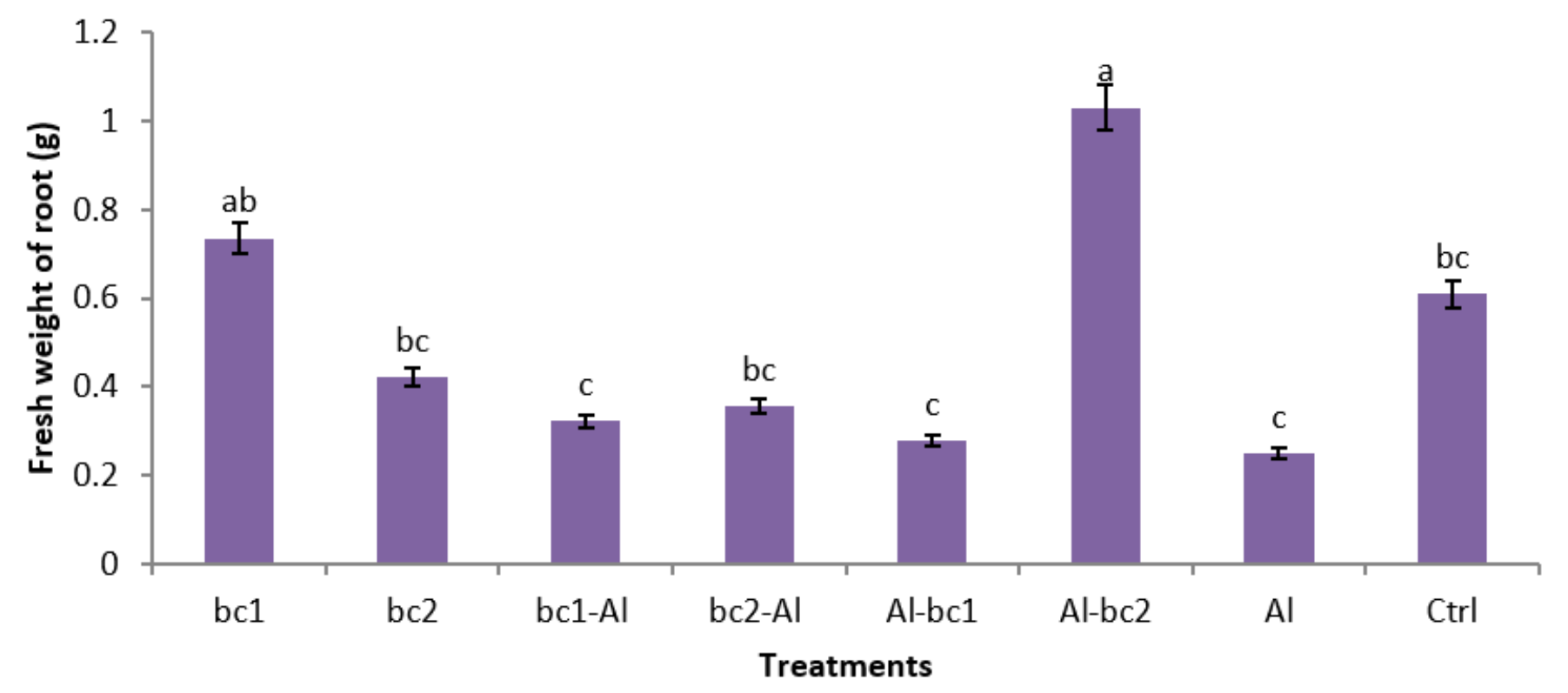

Figure 15

Effects of treatments on fresh weight of root (FWR). *Bars bearing different letters differ significantly $(\mathrm{LSD} \leq 0.05)$

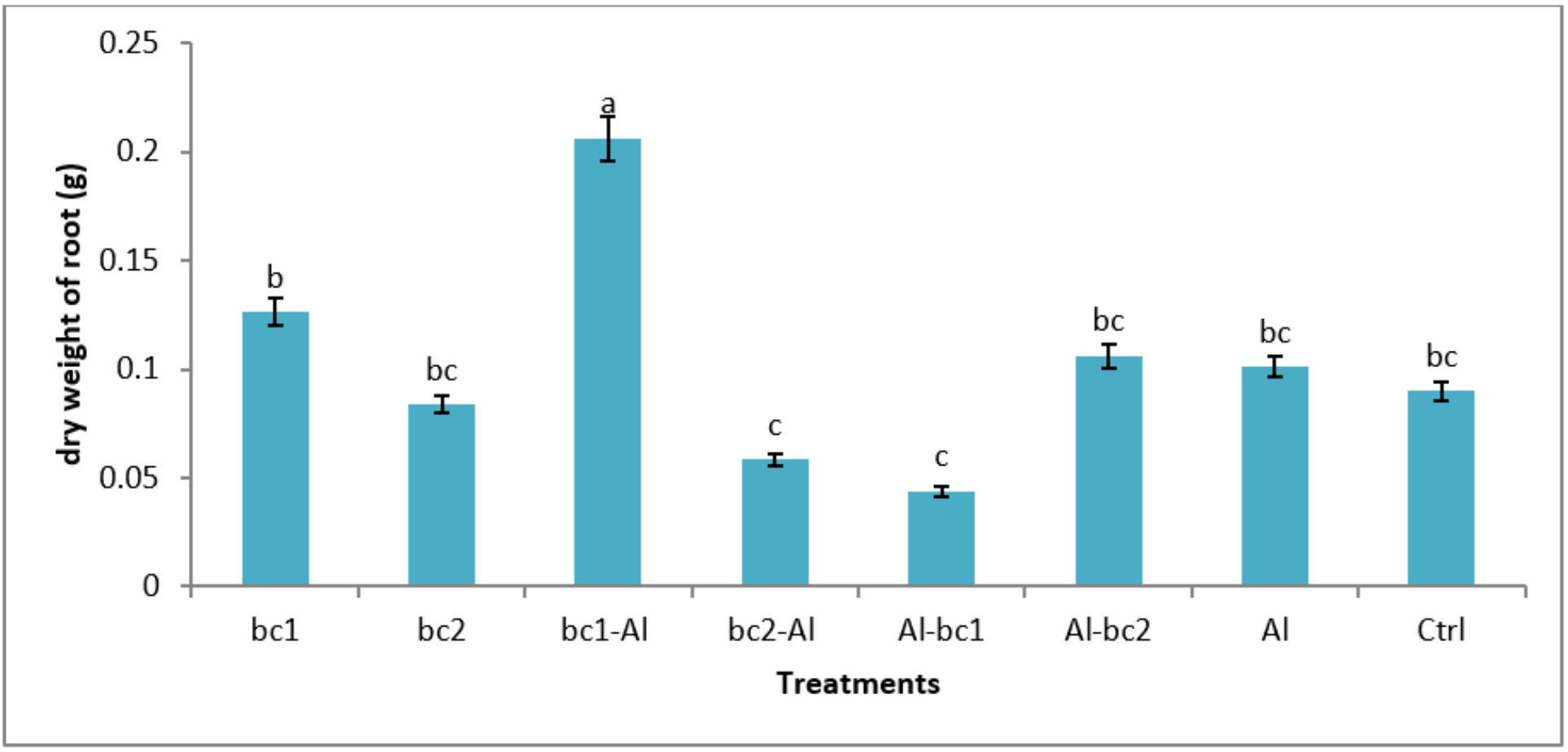

Figure 16

Effects of treatments on the dry weight of root (DWR). *Bars bearing different letters differ significantly $(\mathrm{LSD} \leq 0.05)$ 